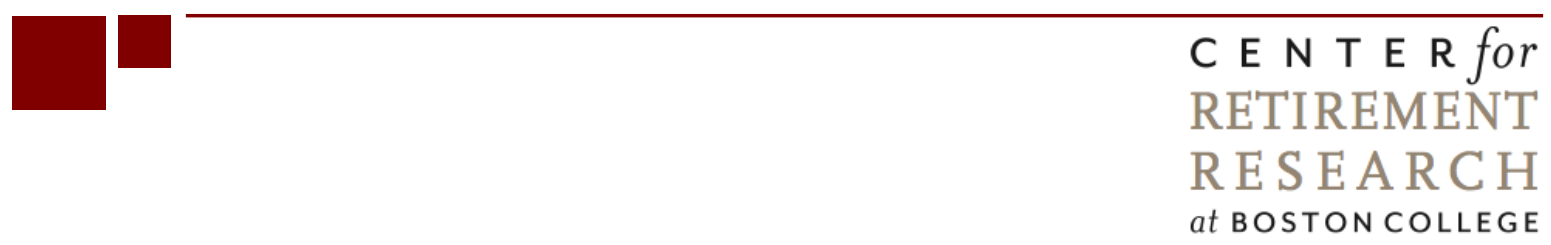

\title{
POINT OF NO RETURN: HOW DO FINANCIAL RESOURCES AFFECT THE TIMING OF RETIREMENT AFTER A JOB SEPARATION?
}

\author{
Matthew S. Rutledge \\ CRR WP 2013-21 \\ Submitted: October 2013 \\ Released: December 2013 \\ Updated: February 2014 \\ Center for Retirement Research at Boston College \\ Hovey House \\ 140 Commonwealth Avenue \\ Chestnut Hill, MA 02467 \\ Tel: 617-552-1762 Fax: 617-552-0191 \\ http://crr.bc.edu
}

Matthew S. Rutledge is a research economist at the Center for Retirement Research at Boston College. The research reported herein was pursuant to a grant from the U.S. Social Security Administration (SSA), funded as part of the Retirement Research Consortium (RRC). The findings and conclusions expressed are solely those of the author and do not represent the views of SSA, any agency of the federal government, the RRC, or Boston College. The author would like to thank April Wu, Norma Coe, Joyce Manchester, and seminar participants at the 2013 Retirement Research Consortium meeting for their helpful comments.

(C) 2013, Matthew S. Rutledge. All rights reserved. Short sections of text, not to exceed two paragraphs, may be quoted without explicit permission provided that full credit, including (C) notice, is given to the source. 


\begin{abstract}
About the Center for Retirement Research
The Center for Retirement Research at Boston College, part of a consortium that includes parallel centers at the University of Michigan and the National Bureau of Economic Research, was established in 1998 through a grant from the Social Security Administration. The Center's mission is to produce first-class research and forge a strong link between the academic community and decision-makers in the public and private sectors around an issue of critical importance to the nation's future. To achieve this mission, the Center sponsors a wide variety of research projects, transmits new findings to a broad audience, trains new scholars, and broadens access to valuable data sources.
\end{abstract}

\author{
Center for Retirement Research at Boston College \\ Hovey House \\ 140 Commonwealth Avenue \\ Chestnut Hill, MA 02467 \\ phone: 617-552-1762 fax: 617-552-0191 \\ e-mail: crr@bc.edu \\ crr.bc.edu
}

Affiliated Institutions:

The Brookings Institution

Massachusetts Institute of Technology

Syracuse University

Urban Institute 


\begin{abstract}
This project uses the Survey of Income and Program Participation to examine the decision to retire after job separation among the increasing number of older individuals who leave a job between 55 and 70, and how this decision varies by labor market conditions and the resources available to the unemployed. Among individuals whose jobless spells end in retirement, most do so within a year after separation. The availability of resources like Social Security retirement benefits, high net worth, and defined benefit pensions appear to encourage more rapid labor force exit and retirement, rather than supporting job seekers during a long search. Surprisingly, retirement is only modestly more likely when the unemployment rate is high, and a greater duration of unemployment insurance benefits has little effect on retirement timing. Poor health and work-limiting disabilities are also associated with more rapid labor force exit and retirement. These results suggest little tolerance for long job searches - regardless of labor market prospects - and indicate that those who can afford to retire will do so rather quickly.
\end{abstract}




\section{Introduction}

The Great Recession cut a swath of joblessness through the American workforce that was unprecedented in one important way. In previous recessions, the brunt of the job losses was borne by younger, lower-paid workers, and these workers again suffered the most in this recession. But the Great Recession also left older workers more exposed than ever before (Munnell and Rutledge 2013). The unemployment rate among those 55 and older reached a record 7.3 percent in August 2010, surpassing 6 percent for the first time since 1950. Even this record unemployment rate among older workers understates the breadth of the suffering, as currently employed individuals may have previously experienced a job loss; indeed, in a slightly younger sample, Farber (2011) finds that 14 percent of individuals over 50 experienced a job loss between 2007 and 2009, surpassing the previous high of 10 percent.

Given the other records set in 2009-2010 - a period marked by the longest average duration of unemployment and the highest ratio of unemployed per vacancy - many older unemployed workers grew discouraged, stopped looking for work, and began to consider themselves retired (Coile and Levine 2011a). Others bore down and continued searching, unable to retire due to losses in their financial portfolios and home values, or motivated by the opportunity to maintain as many as 99 weeks of unemployment insurance (UI) benefits (Rothstein 2011). Among people over 55, the labor force participation rate actually increased by a percentage point between 2007 and 2009. But this increase was concentrated among workers who had not yet reached age 62 and were not yet eligible for Social Security retirement benefits (Munnell and Rutledge 2013). Not coincidentally, more than half of the workers who lost their jobs after turning 62 left the labor force within nine months of their separations, as opposed to less than 30 percent of workers age 50-61 (Johnson and Butrica 2012).

The difference in the responses to the recession before and after age 62 implies that the decision to leave the labor force and retire depends crucially on the availability of resources to buttress consumption, both during the jobless spell and after retirement. This project investigates the association between retirement timing and the availability of Social Security and UI benefits, financial and pension wealth, and labor market prospects, using high-frequency labor market data from the Survey of Income and Program Participation. This project further investigates how these factors have changed over time, as pension coverage has evolved and older workers' exposure to labor market volatility has increased. 
The loss of income - and, potentially, health insurance coverage - makes retiring earlier than one had planned costly: after a decade-long decline in early claiming, the proportion of 62 year olds claiming Social Security retirement benefits spiked in 2009 (Bosworth and Burtless 2010; Johnson and Mommaerts 2010), decreasing early claimants' benefits by nearly 5 percent each month for the remainder of their lives (Rutledge and Coe 2012).

An extensive literature documents that higher unemployment rates are associated with earlier retirement (Coile and Levine 2007, 2011a, 2011b; von Wachter 2007; Munnell et al. 2008; Friedberg, Owyang, and Webb 2008). Other research focusing on individual job loss finds that separation increases the likelihood that individuals exit the labor force (Chan and Stevens 1999, 2004; Stevens and Chan 2001; Tatsiramos 2010). Less is known, however, about how an individual's job search influences the timing of the retirement decision, due to a combination of data limitations and the context-dependent definition of "retirement." Only Hallberg (2011) investigates the timing of the retirement decision in a hazard model framework, but his work focuses on Sweden, which differs from the United States in the structure of its UI and retirement benefit systems.

This project provides the first estimates of the association between the timing of retirement and unemployment duration in the United States, emphasizing how this relationship is influenced by the availability of social insurance benefits, financial assets, pension coverage, and macroeconomic conditions.

The results indicate that retirement occurs early during one's jobless spell. Surprisingly, the timing of retirement has only a slight correlation with labor market conditions and the availability of UI benefits. Rather than using resources like financial wealth, Social Security benefits, and defined benefit pensions to make ends meet during a long job search, the availability of these resources is associated with a higher probability of retiring in any given period. Jobless individuals in poor health or with work-limiting disabilities also retire sooner, and those with working spouses have similar jobless spell durations to those whose spouses have already stopped working. Given that about half of retirements end immediately after job separation, and the majority of the remainder retire within a year, the older unemployed appear to have little desire, or ability, to maintain long job searches. 


\section{Data and Methodology}

The Survey of Income and Program Participation (SIPP) interviews each individual in a panel of households every four months for a two- to four-year period. The survey covers labor force status, earnings, job characteristics, job search activity among the unemployed, public program participation and benefit levels, health insurance coverage, and household and family structure. These core variables, collected for each month within the four-month wave, are supplemented by routine topical modules regarding assets and liabilities, pension coverage, and health status, among many other topics. New panels began each year from 1990-1993, plus 1996, 2001, 2004, and 2008. ${ }^{1}$

Although the Health and Retirement Study (HRS) is more commonly used for analyses of retirement, SIPP provides several advantages. Most important, though SIPP follows households for a shorter period, data are available for each month with a far shorter recall window (four months instead of two years), with more detailed information on job search activity. SIPP began earlier than HRS, which started in 1992, and has released data through late 2012, so the analysis of trends in retirement behavior includes a longer period. ${ }^{2}$

The sample for this study consists of individuals from the 1990-2008 SIPP panels who are observed leaving a job between the ages of 55 and $70 .{ }^{3}$ A job separation occurs in month $t$ if individual $i$ works all weeks in month $t-1$, fewer than four weeks in month $t$, and no weeks in month $t+1$; thus, $i$ must have had a job for at least a full month, and the jobless spell must last for at least one month.

In each month following job separation, $i$ experiences exactly one of four potential outcomes: (1) continuing a job search, (2) finding a new job, (3) censoring, or (4) the outcome of interest, either retiring or permanently exiting the labor force. Job search -i.e., continuing the jobless spell - is the base outcome. Re-employment is the reverse of job separation: $i$ finds a new job in month $s$ if he works zero weeks in month $s-1$, at least one week in month $s$, and all weeks in month $s+1$; re-employment thus requires at least one full month of work at the new job.

\footnotetext{
${ }^{1}$ Additional panels began each year from 1984-1989, but these data are not used in this study.

${ }^{2}$ The most substantial advantage that HRS has over SIPP - a long panel lasting up to 18 years for some respondents - is less relevant for this study, because jobless spells among workers 55 and older are likely to end - one way or another - within a year or two of job separation, so relatively few spells are censored.

${ }^{3}$ This study does not differentiate between voluntary and involuntary separations. Because the sample includes only those who do not retire or leave the labor force immediately, the reason for job transitions is irrelevant, even if selfreported reasons for transitions were reliable.
} 
Censoring occurs when the individual is not interviewed by the SIPP, either because of individual attrition or the scheduled conclusion of the SIPP panel.

Unlike the HRS, SIPP has no single established method of determining whether a respondent is retired. This study uses a combination of variables to derive multiple definitions of retirement, based on a sliding scale of stringency.

The most relevant retirement variable is based on $i$ 's answer to the question, "What is the main reason [the respondent] did not work at a job or business during the reference period?" The strictest definition of retirement requires the individual to answer "retired" for that wave, while ceasing work and job search for the remainder of $i$ 's time in the SIPP. ${ }^{4}$ The "quasi-strict" definition of retirement also requires "retired" as an answer, but only requires $i$ to not work or search for a job for at least a four-month period, thereby allowing the individual to "un-retire."5 The loose definition of retirement also requires $i$ to not work or search for at least four months, but allows other possible answers in addition to "retired": "unable to work because of chronic health condition or disability," "taking care of children/other persons," or "not interested in working at a job.",6

A similar variable that is of limited use to this study asks the respondent why he left his previous employer. Among those who eventually retire under the definitions in the paragraph above, about half report that they left their job to retire, or answer that they are not working because they are retired in the question discussed in the previous paragraph. Because this study is primarily interested in those who retire only after some period of job search, the regression sample includes only those who do not report retiring at the time they leave their job, and do not consider themselves retired at the first interview month after separation. ${ }^{7}$

\footnotetext{
${ }^{4}$ The respondent is asked the number of weeks he searched for a job in each month of the wave; to qualify as not searching, the number weeks in the month spent looking for a job must be equal to zero.

${ }^{5}$ The four-month moratorium on work or job search need not coincide with a full wave; for example, $i$ might search for at least a week during each of the first two months of wave $w$, answer "retired" in the interview month of wave $w$, and then avoid work or search for at least the first two months of the next wave, $w+1$.

${ }^{6}$ The other possible reasons, all of which disqualify someone from being marked as retired in that wave, are being temporarily unable to work because of illness or injury, pregnancy or childbirth, going to school, unable to find work, on layoff (temporary or indefinite), or other.

${ }^{7}$ This sample exclusion matches the relevant retirement definition: when the potential outcome is retirement under the strict or quasi-strict definition, only those who report leaving their job for "retirement or old age" are excluded. When the potential outcome is, instead, the loose definition of retirement, those who leave their previous job for "retirement or old age," "other family/personal obligations," "own illness," or "own injury" are excluded. In each regression with retirement as a potential outcome, the sample further excludes those who are within four months of censoring, because by definition no one is at risk of retiring by the quasi-strict or loose definitions. Though not required by the strict retirement definition, this restriction eliminates the possibility that the strict retirement
} 
An important limitation of this method of defining retirement is that SIPP began asking the question about why the respondent is not working starting only in the 1996 panel. In order to compare labor market activity trends among older individuals over a longer period of time (1990-2012), this study also analyzes the decision to permanently exit the labor force. Labor force exit simply requires the end of job search activity, regardless of the label put on the individual's current status; that is, whether he's retired or discouraged, all that matters is that's no longer actively seeking a job. Because some individuals, however, might drift in and out of labor force participation (Elsby, Hobijn, and Sahin 2013), the definition of "permanent" must ensure that one is not considered to have exited the labor force for good just because the panel happened to end during one of these drifts. ${ }^{8}$ The respondent is considered to have left the labor force permanently if he has no weeks working or searching for at least the final six months that he is in the SIPP panel. As with retirement, the relevant population "at risk" consists of those who do not leave the labor force right away, but do so only after a period of unsuccessful job search. The sample, therefore, is limited to individuals who stay in the labor force at least one month after separation and keeps only those person-months at least six months from the end of the individual's sample window, after which any ongoing spells are considered censored.

Table 1 details how the sample is selected for each outcome. Of the 68,000 individuals in the SIPP working in their 50s, 17,000 left a job between ages 55 and 70, inclusive. ${ }^{9}$ The second and third panels of Table 1 make clear that just under one-half of those individuals who left a job during this age range retired or left the labor force immediately. After excluding these individuals, and those whose separation occurs too close to the end of their SIPP sample window, the remaining sample includes 6,460 individuals for the strict and quasi-strict retirement regressions, 4,700 individuals for the loose retirement regression, and 3,400 individuals for the labor force exit regression.

definition captures people who are not observed long enough to show up as retired by the other two definitions; otherwise, someone who reports being "retired" with only two more monthly observations before censoring would be marked as "strictly" retired, but not "quasi-strictly," even though he could get a job soon after SIPP stops interviewing him.

${ }^{8}$ Note that permanent labor force exit requires zero weeks of working and searching, while re-employment requires at least one full month of work. This definition will mark individuals with spotty employment experiences - some weeks worked, but never all four or five weeks in a month - during the remainder of the panel as neither fully reemployed, nor fully out of the labor force.

${ }^{9}$ The sample restriction excludes those who are already without a job when first sampled by the SIPP, but if SIPP's sampling procedure works properly, their labor market outcomes and use of resources should be no different than those who are observed leaving a job. 
The literature on "seam bias" in SIPP suggests that the bulk of job separations will occur in the interview month - the fourth reference month - of the wave. SIPP staggers interviews so that one-quarter of the panel is interviewed in each month. As a result, any given reference month in any given panel occurs in four different calendar months; for example, the first reference month of the first wave of the 2008 panel is May 2008 for the first one-quarter interviewed in that panel, June for another quarter, July for another quarter, and August for the final "rotation group." The rotating nature of the panel should ensure that status transitions including job separations - occur with approximately equal probability in each reference month. Instead, numerous studies have documented that transitions are overwhelmingly more likely to occur in the fourth reference month, suggesting recency bias on the part of respondents (Ryscavage 1988, Young 1989, Marquis and Moore 1990).

To correct for seam bias, this analysis uses person-waves as the unit of observation after the job separation. ${ }^{10}$ The outcome for a jobless spell that is ongoing as of the fourth reference month of wave $w-1$ is re-employment, censoring, or labor force exit/retirement, whichever occurs first in wave $w .^{11}$

The key independent variables capture the relationship between retirement or labor force exit and the resources available to the jobless individual, both during the jobless spell and in retirement. $^{12}$ Each regression includes the state unemployment rate to capture labor market prospects; some specifications include interactions with the state unemployment rate to capture the differential labor market prospects by age, remaining UI eligibility, and the duration of the jobless spell.

Perhaps the most important independent variable is the jobless individual's age during the wave. Individuals who have reached age 62 can fall back on Social Security retirement benefits, providing a reliable income stream. While Social Security claiming often coincides with retirement, many beneficiaries continue working or searching for a job: 54 percent of SIPP respondents working all weeks in a month at ages 62 to 70 are receiving Social Security

\footnotetext{
${ }^{10}$ Job separations use information from each month, not just the interview month. The 197 person-waves with two job separation use the latter separation.

${ }^{11}$ A complementary reason to collapse person-months into person-waves is that the variable that identifies retirement varies only by wave, rather than by month. Labor force exit, on the other hand, varies by month, but seam bias concerns prevail: in a multinomial logit of person-months (instead of person-waves), the estimated marginal effect for every fourth month dummy is much larger than the dummies for surrounding months, even after including a dummy for interview month, à la Ham, Li, and Shore-Sheppard (2009).

${ }^{12}$ Summary statistics for all independent variables are reported in Table A1.
} 
benefits. ${ }^{13}$ This statistic indicates that jobless individuals over 62 often fall back on Social Security benefits either temporarily (with benefits potentially deferred by the "earnings test" if the respondent finds a new job) or to supplement income from an eventual job. The model includes an indicator for whether the individual has reached his $62^{\text {nd }}$ birthday by the end of the wave; this variable avoids the endogenous decision to actually claim Social Security benefits and focuses just on the eligibility to do so. ${ }^{14}$

Unemployment insurance benefits are one factor that may keep older jobless individuals in the labor force. The regression model includes a categorical variable for remaining UI eligibility: (1) the individual is eligible for UI and does not exhaust his benefits during the interview wave, (2) the individual exhausts benefits at some point during the wave, or (3) the individual is no longer eligible for UI at any point during the wave (the omitted condition). This information is collected from U.S. Department of Labor reports on state UI parameters. ${ }^{15}$

Most higher-net-worth individuals who leave their jobs would not be in the sample, as they are more likely to report leaving their job for retirement or to never spend time searching after a separation, whether or not the job separation was planned well in advance. Among those who do search before declaring themselves retired, wealthier individuals likely retire earlier. Information on net worth is collected as part of annual topical modules and merged with the person-wave nearest to the wave of collection. The analysis controls for the individual's net worth linearly, as well as a dummy variable for missing wealth information. ${ }^{16}$

Retirement is also easier to manage for those who have employer pensions. SIPP collects information on defined benefit (DB) and defined contribution (DC) pension plans from the current job and any previous jobs as part of a once-per-panel topical module. ${ }^{17}$ The model

\footnotetext{
${ }^{13}$ This calculation is for all workers, not just those who eventually experience a job loss and thus enter the sample.

${ }^{14}$ In the absence of earnings data, the model implicitly assumes that any individual has accumulated enough credits to be eligible for Social Security benefits by his $62^{\text {nd }}$ birthday, which should be true for most workers active after age 55. Estimates from alternative models that instead use categorical variables for age - reaching one's $62^{\text {nd }}$ birthday in the current wave, between one's $62^{\text {nd }}$ birthday and reaching the Full Retirement Age (FRA), reaching one's FRA in the current wave, and after FRA - show similar magnitudes for each category, suggesting that continuing the jobless spell depends only on whether the individual has reached the threshold of initial Social Security eligibility, not any subsequent milestones.

${ }^{15}$ See Rutledge (2012) for more details on the state UI data.

${ }^{16}$ A linear specification is preferred to a log-linear specification due to the 14 percent of individuals with zero or negative net worth. Alternative specifications that include net worth quintiles (by year) show a monotonic pattern in each regression, suggesting little non-linearity in labor market decisions with respect to net worth.

${ }^{17}$ The 2008 panel is the only panel to collect pension information more than once; this information is merged into the closest person-waves. Though the information on DC plans in the current job is quite detailed - including employees' and employers' contributions - information on plans from previous jobs is much more limited, and the
} 
includes two (not mutually exclusive) indicator variables for whether the individual reports any DB or DC pension coverage. As with Social Security benefits, DB pension receipt does not correspond perfectly with retirement; 28 percent of workers age 62 to 70 report income from a DB plan.

Another important factor is the age and work status of one's spouse. Married couples tend to retire together; Gustman and Steinmeier (2002) estimate that having a retired spouse increases the probability of being retired by as much as being about one year older. Thus the model controls for marital status, and includes indicators for whether the spouse is working and whether the spouse has reached age 62.

The model also includes a comprehensive set of demographic variables, including gender, race, and Hispanic origin. Categorical variables include citizenship, education, and family income as a percent of the federal poverty line. The model includes year dummies to account for time trends in retirement behavior, including the trend toward later retirement (Muldoon and Kopcke 2008, Bosworth and Burtless 2010). The model also includes two indicator variables capturing the individual's health status in the interview wave: an indicator variable for whether the individual reports fair or poor health and an indicator for whether the individual reports being limited or unable to work due to a health condition. ${ }^{18}$ Finally, the model controls for whether the individual had employer-sponsored health insurance before job separation. This is of interest, because people who had been relying on their employment for health coverage likely will aim to take a new job with health benefits relatively quickly or fall back on retiree health insurance benefits from a previous job.

Importantly, the model controls for duration dependence by including a set of indicators for the number of months since the individual left his job. These indicators, when graphed, display the unexplained retirement, labor force exit, or re-employment hazard pattern. Indicators are grouped in two-month intervals up to 21 months, with grouped indicators for months 22 through 25, 26 through 29, and 30 or more months after job separation.

only information collected for DB plans is whether the individual participates, so the model includes only the extensive margin of DB and DC coverage. The topical module information is supplemented with information from the core: if the individual reports any pension income in any wave, the individual is considered to have either a DB or DC plan.

${ }^{18}$ The information on work-limiting or work-preventing health conditions is collected for each wave in the core. The individual's self-reported health status on a five-point scale is asked multiple times each panel, as part of topical modules on disabilities and health care spending; this information is merged with the nearest interview wave. 
The model uses SIPP-provided weights that capture the complex survey design. All tables report the marginal effects - i.e., the derivative of the outcome variable with respect to the particular variable, averaged over all individuals in the sample - that take into account the nonlinearity of the multinomial logit model, including interactions (Ai and Norton 2003). Standard errors for the marginal effects are calculated by the Delta method.

\section{Results}

Unconditional Results. Table 2 compares the shares of older workers who retire, find a new job, or are censored by individual characteristic. Over the past 16 years, fewer spells ended in retirement. During the expansion surrounding the high-tech bubble, 47 percent of jobless individuals 55 or older who did not retire immediately eventually retire; during the Great Recession, by contrast, only 35 percent eventually retire. Only 15 percent of those who are not yet eligible for Social Security retire, with 49 percent finding a new job. After Social Security becomes available, 20 to 25 percent end their jobless spell by retiring. When the end of jobless spell coincides with the end of UI eligibility, 24 percent retire; when, instead, the end of the spell occurs after UI eligibility is exhausted, only 7 percent end in retirement. The probability that jobless spells end in retirement does not vary much by wealth, spouse's work status, state unemployment rates, or DB pension holding, but spells are more likely to end in retirement when the individual holds a DC pension (surprisingly), has a work limitation, or reports being in fair or poor health.

Table 3 reports the average duration of a spell that ends in retirement or re-employment by individual characteristic. ${ }^{19}$ As expected, given that fewer spells end in retirement in recent years, the average duration of job search before retirement is longer in 2008-2012. As individuals age, not surprisingly, their time until retirement grows shorter, but the duration before finding re-employment hovers around seven months regardless of their age. Spells ending in retirement at the same time that UI is exhausted conclude almost one month earlier on average than spells ending in re-employment around UI exhaustion, a statistically significant difference. The widest gap between retirement and re-employment in the duration of spells is in the middle quintile of net worth, where spells ending in retirement last almost 1.5 months longer than spells ending in a job. Unmarried individuals wait longer to retire than those with the support of a

\footnotetext{
${ }^{19}$ Censored spells (not shown), not surprisingly, last longer on average.
} 
working spouse or with a spouse who is no longer working; the latter finding is consistent with the joint retirement decision.

Retirees in states with high unemployment rates spend more time searching: the average duration is more than a month longer than those who retire in low unemployment states, and 0.7 months longer than residents of similar states who find re-employment. ${ }^{20}$ The time before retirement is 0.8 months longer without a DB plan than with one, but those with a DC pension retire more rapidly than those without; both findings are consistent with the greater mobility allowed by 401(k) plans compared to traditional pensions. Finally, fair or poor health and work limitations are both associated with longer durations before both retiring and finding reemployment; these unhealthy individuals, who are nonetheless still working after 55, are less eager to retire than those without health concerns, but they may also have trouble finding a new employer to accommodate their health needs.

The summary statistics by age suggest that the availability of Social Security retirement benefits plays an important role in the decision to retire after a job loss, even though many continue searching for a job after they become Social Security beneficiaries. Table 4 examines the timing of claiming for those leaving a job - but not immediately retiring - before and after their $62^{\text {nd }}$ birthdays, when Old Age and Survivors Insurance (OASI) first becomes available. Among those who leave their jobs before age 62 but are observed in SIPP at least once after turning 62, just less than half claim OASI (Panel A). But among those observed claiming OASI at some point, nearly all claim when benefits are first available. Still, Social Security claiming does not imply retirement (and none of the retirement definitions use Social Security receipt explicitly); 35.3 percent of individuals who leave a job, but eventually find another, claim benefits at 62. Moreover, a little more than half of those leaving their jobs at or after age 62 are already receiving OASI benefits (Panel B). Around 21 percent are not observed claiming OASI, but the plurality of those that do start receiving Social Security benefits claim within the same wave that they leave their job. These findings suggest that Social Security is a resource that could help individuals support themselves during a job search, and by no means is claiming Social Security an indicator that job search has ceased.

Multinomial Regression Analysis. Table 5 reports the results of three multinomial regressions, where re-employment is one outcome and one of the three definitions of retirement 
(strict, quasi-strict, and loose) is the other. The top line reports that, in any given wave, between 15 and 20 percent of jobless spells ended in re-employment; this varies by the definition of retirement, as spells can end for one kind of retirement but not another. The probability in a given wave of strict retirement is 8 percent; quasi-strict retirement is 11 percent; and loose retirement is 19 percent, almost matching re-employment.

A higher state unemployment rate is associated with a lower probability of quasi-strict or loose retirement, along with a lower probability of re-employment by any definition. Although the relationship between retirement and local labor market conditions is statistically significant, the estimated magnitude is quite small: a one-percentage-point increase in the state unemployment rate is associated with only a 0.8-percentage-point decrease in retirement (loose definition), or about a 4-percent decrease from the mean of 19 percent. The relationship between strict retirement and the unemployment rate is negligible.

In contrast to the results for macroeconomic conditions, the relationship between age and retirement is substantial. Having Social Security retirement benefits available increases the probability of retirement by 10.5 to 13.2 percentage points, compared with individuals who are 61 and younger and ineligible. The retirement hazard, defined loosely (far right column), is more than one-half (10.8 divided by the mean of 19.0) higher at and after age 62, compared to before one's $62^{\text {nd }}$ birthday. Re-employment is also less common at and after age 62 .

Despite indications to the contrary in Tables 2 and 3, retirement is not significantly associated with UI eligibility. Re-employment is more common in the months that UI is available than in the months after UI has been exhausted, but the estimated magnitudes for retirement are relatively small and inconsistently signed.

The picture for wealth is somewhat clearer. As net worth increases, retirement becomes more common in any given wave, but the magnitude of the correlation is not large: a one standard deviation increase in net worth (about $\$ 427,000$, on a mean of $\$ 275,000$ ) is associated with a 1.3 percentage point, or 7 percent, increase in the probability of retiring (loose definition) in the given wave. Having a DB pension plan has a larger correlation with the retirement hazard: retirement is 4 to 7 percentage points (or 38 to 60 percent of the mean hazard) more likely if the individual has DB coverage from any previous job. DC plans are associated with a statistically significant but small reduction in the strict retirement hazard; there is no relationship between 
DC coverage and the other definitions of retirement, while DC coverage is associated with an increase in the re-employment hazard.

The marginal effects for the marital status variables for strict and quasi-strict retirement accord with previous research that suggests the importance of the joint retirement decision. Married individuals whose spouse does not work are 1.3 to 5.4 percentage points (17 to 29 percent above the mean) more likely to retire in a given wave than are the unmarried. But the marginal effect of a working spouse more than offsets the married marginal effect for strict and quasi-strict retirement, so that the combined effect on the retirement decision is not statistically significantly different from single people. With loose retirement, on the other hand, the working spouse effect is negligible, so married individuals retire at the same rate regardless of whether their spouses are working or not. In all specifications, spouse's age does not appear to play a role in one's own retirement decision.

Most other variables in the regression are insignificant; there is little difference by education, race, or Hispanic origin. ${ }^{21}$ Other results, including those not reported here, are inconsistent - low-income individuals are less likely to retire by the strict and quasi-strict definitions but not by the loose definition, and those who obtained health insurance through their former job are less likely to retire in any given wave only by the loose definition. The third-tolast row in Table 5 reports that women are more likely to retire by the loose definition, but less likely to retire by the quasi-strict definition; neither estimate is qualitatively large, but these opposing results are consistent with women retiring to take care of an ailing spouse, elderly parent, or grandchild. Finally, those with work limitations are less likely to retire by the strict or quasi-strict definition, but are more likely to retire by the loose definition; given that the loose definition includes those who retire for chronic illness or injury, this result is to be expected. Fair or poor health, on the other hand, has a consistently positive correlation with retirement.

Table 6 reports results of similar multinomial regressions in which the outcomes are reemployment or labor force exit. Unlike retirement, labor force exit is available for the 19901993 panels, so the first two columns report results from all years, while the second pair of columns reports results from the 1996-2012 period that is also used in the retirement regressions in Table 4. The results are largely similar between the two periods, however; the mean hazard

\footnotetext{
${ }^{21}$ Full results are available upon request.
} 
rate is 8 percent in both periods, and most variables have similar magnitudes and qualitative findings.

As with retirement, labor force exit has a small negative though statistically significant correlation (only for the full sample) with the state unemployment rate. With respect to age, the general picture is the same as the retirement regressions: Social Security benefits allow for a quicker exit from the labor force. As with retirement, labor force exit is not significantly correlated with UI eligibility, and the probability of leaving the labor force is higher among those with DB pensions. Similarly, labor force exit is more common for married individuals with nonworking spouses, but it is no more or less common for married individuals with working spouses, compared to single individuals. One difference with the retirement results is that net worth is not statistically significantly correlated with labor force exit. ${ }^{22}$

The correlations between retirement and gender, and retirement and health, differ by whether the definition includes health-related reasons for not working. The three estimates at the bottom of Table 6 come down on the side of the loose retirement definition. Women are more likely to exit the labor force in any given wave over both samples; the correlation is of a similar magnitude and significance to the loose retirement definition. The relationship between health status and retirement depend on whether the definition includes retirement for health reasons; the estimates for labor force exit, which does not have a direct relationship to health, also matches the loose retirement estimates, suggesting a positive correlation between poor health and leaving the labor force permanently.

Figure 1 displays the unexplained retirement hazard rates - that is, the marginal effect for the indicator variables for the number of months since job separation, relative to $12-13$ months after separation, after controlling for other factors. The graph begins four months after separation, since those who left their job for retirement are not in the sample. Even with this exclusion, retirement is most common soon after job separation by any definition, and the decline is generally monotonic for more than a year thereafter. Not surprisingly, the loose definition of retirement is most common, but the likelihood of retiring (loosely defined) falls rapidly between 6-7 months and 12-13 months after separation. This sharp decline occurs four

\footnotetext{
${ }^{22}$ Unlike the retirement regressions, where the correlation between net worth and retirement is uniformly linear, the relationship between net worth and labor force exit exhibits signs of non-linearity. For the full period, labor force exit is statistically significantly less likely in the $2^{\text {nd }}$ and $4^{\text {th }}$ wealth quintiles compared to the highest quintile, but only the $2^{\text {nd }}$ lowest wealth quintile for the 1996-2012 period.
} 
months earlier for strict and quasi-strict retirement and is more gradual for labor force exit. Other than loose retirement, the other four series continue to decline until about 16-17 months; after that, there is a slight rebound, and loose retirement is about as common just over two years after separation as it is just under a year after separation. These results emphasize that retirement and labor force exit are most likely early in the jobless spell; if an older individual has not retired within the first 8-12 months, he is likely to remain on the fringe of the labor force for another year or more.

While the unconditional correlations in Table 3 indicate that retirement and local labor market conditions might be related, the regression results thus far indicate that a higher unemployment rate is associated with a very slight delay in retirement. ${ }^{23}$ To test the robustness of this finding, additional specifications are estimated that include interactions between the unemployment rate and categories for age, remaining UI eligibility, and months since separation. Table 7 presents the level and interaction effects and standard errors for age and UI eligibility; the level effects for non-interacted variables are largely unchanged.

Only a few of the interaction effects are statistically significantly different from zero; accordingly, the level effects for age are nearly identical to the results from Tables 5 and 6 . The previously noisier estimates for UI eligibility, however, exhibit more change: now the early months of UI eligibility are associated with almost half as many retirements (defined loosely) than in the months after UI becomes unavailable, but this result is just barely statistically significant. The the age interaction suggest that strict retirement is slightly more rapid in waves with higher unemployment rates among people who have reached at least their $62^{\text {nd }}$ birthdays, but this is the only one of the 15 interaction effects reported in Table 7 that is statistically significant.

To get a sense of the magnitude of these interactions, Figures $2 \mathrm{a}$ and $2 \mathrm{~b}$ plot the predicted probability of retiring (under the loose definition) in each month after job separation for individuals at ages 55-61 and 62-70, respectively. These simulations compare the predicted retirement hazard for these age groups at two different unemployment rates: 5 percent, which is the average unemployment rate between January 2004 and December 2007 (the expansion); and

\footnotetext{
${ }^{23}$ The marginal effect of state unemployment rates in multinomial regression models where it enters as a quadratic are smaller and less statistically significant than the results reported in Tables 4 and 5.
} 
8.3 percent, which is the average unemployment rate from January 2008 to December 2012 (during the Great Recession and early recovery).

For the hypothetical individual who is not yet eligible for Social Security, retirement is actually more likely in the first nine months when the unemployment rate is lower compared to the weaker economy, by between 4 and 7 percentage points (Figure 2a). From 10 to 19 months, though, retirement becomes more common at the higher unemployment rate than at the lower unemployment rate, and thereafter is approximately the same. The pattern is nearly identical for the hypothetical individual who has already reached age 62 , though the predicted hazard is somewhat higher in each month (Figure $2 b$ ). But none of the interaction effects between the unemployment rate and months since job separation are statistically significant, indicating that the timing of retirement is unrelated to the state of the labor market, regardless of whether the individual is age-eligible for Social Security retirement benefits.

Results by Age. Table 8 tests the robustness of the loose retirement and labor force exit estimates across three age categories: before age 62, from age 62 up to the FRA, and at and after the FRA. Among 55-61 year olds (first two columns), labor force exit is statistically significantly less likely when the unemployment rate is high, but as with the full sample, the magnitude of the effect is small (about 10 percent of the mean hazard rate). Both retirement and exit are significantly less likely when UI is still available, but the wave of UI exhaustion is not statistically different from waves without UI. As relative net worth increases, retirement becomes more likely, and those with DB pensions are more likely to retire or exit the labor force. Married individuals, women, and those with work limitations or fair or poor health are also more likely to retire or exit in any given wave after job separation among those under age 62 .

The relationships between each of the resources available to support an unemployed individual and his decision to retire or leave the labor force changes once Social Security benefits become available, though not in any consistent way (last four columns). After age 62 but before the FRA, DB pension coverage is associated with more rapid retirement or labor force exit, but there is no significant connection with net worth or UI benefits. Once the individual reaches their FRA, however, the correlation between retirement and DB pension coverage is no longer statistically significant, but the retirement becomes stronger and statistically significant with greater net worth or upon UI exhaustion. Retirement is statistically significantly less likely 
among those past the FRA when the labor market is weak but, as in other specifications, the estimated correlation is small.

Results by Period. To test whether the correlations with the retirement hazard have changed over time, the model is also estimated by period: 1996-2000, 2001-2003, 2004-2007, and 2008-2012 (Table 9). These time periods line up with the business cycle, but also coincide with the beginnings and ends of SIPP panels. Loose retirement and the unemployment rate have a statistically significant negative coefficient only in the 2001-2003 period, but as with previous results, the magnitude is small. The relationship between retirement and Social Security ageeligibility is consistently positive over time, but somewhat weaker for the 1996-2000 period; the same is true for women and those with negative health indicators. In no period is the correlation between loose retirement and UI eligibility statistically significant. The correlations between retirement and both net worth and DB pension coverage are positive throughout, though neither is statistically significant in the 2004-2007 period. On the whole, the results are consistent across business cycles.

Results for the Non-Disabled. The main results indicate that having a health condition that limits one's ability to work has one of the strongest and most consistent estimated correlations with retirement and labor force exit, especially among the unemployed younger than $62 .^{24}$ This result suggests that many work-limited individuals may fall back on Social Security Disability Insurance (SSDI) rather than wait for retirement benefits from Social Security or DB plans. Previous literature has found that SSDI application is strongly correlated with the unemployment rate (see Autor and Duggan, 2006, for a review) and that unemployed individuals are more likely to apply, especially after UI benefits are exhausted (Rutledge 2012a). Since a disability applicant must have income below the Substantial Gainful Activity level (\$1,040 per month in 2013), many applicants will drop out of the labor force.

To test whether SSDI applicants drive the above results, Table 10 presents estimates that exclude the 2,900 unique individuals (approximately 15 percent of the sample) who report receiving SSDI benefits at any point while observed by the SIPP. ${ }^{25}$ The outcome variable in the

\footnotetext{
${ }^{24}$ Work-limited individuals have an incentive to apply for SSDI even after reaching age 62. If they are successful, an SSDI applicant receives the amount he would have received from OASI at their FRA with no actuarial adjustment for early claiming (Benitez-Silva and Yin 2011). Still, few OASI beneficiaries apply for SSDI benefits, and their decision to do so appears to be uncorrelated with macroeconomic conditions (Rutledge 2012b).

${ }^{25}$ Ideally, the sample would be restricted to individuals who do not apply for SSDI, but SIPP includes information only about SSDI receipt, i.e., successful application.
} 
first and second columns is loose retirement; the first column includes the full sample (comparable to Table 5, column 3), while the second column includes only those waves where the individual is age 55-61 (comparable to Table 8, column 1). The outcome in the third column is labor force exit, using the full 1990-2012 sample (comparable to Table 6, column 1). The patterns of statistical significance, and most estimated magnitudes, match the earlier results almost exactly. The one difference is that each regression has a statistically significant negative marginal effect for UI eligibility (pre-exhaustion), though the magnitudes of the marginal effects are not significantly different from the estimates on the unrestricted sample. The marginal effects for work limitation are also slightly smaller in magnitude - fittingly, as the individuals most likely to report a work limitation are also those most likely to receive SSDI benefits at some point - though the differences are not statistically significant. While joblessness may push some to retire or exit for SSDI application, their responses to the available resources does not appear to be appreciably different than those who retire or exit without entering the SSDI program.

\section{Conclusions}

Older workers, understanding that their retirement years will be, in all likelihood, longer and less secure than the previous generation, report time and again that they plan to work longer (Munnell and Rutledge 2013). Yet the proportion of older workers finding themselves jobless has increased over time, and the lure of retirement, instead of a difficult job search, may be hard to resist. Yet many are making the retirement decision amid a diminished ability to support one's pre-retirement lifestyle. This project explores the interaction between these two competing forces, examining how long jobless individuals age 55 and over are willing to search for a new job before they reach their "point of no return."

The results suggest that for job separations that do not result in an immediate retirement, half of the jobless spells end in retirement and half in re-employment. Among individuals whose jobless spells end in retirement, most of them do so within a year after separation. The availability of resources like Social Security retirement benefits, high net worth, and defined benefit pensions appear to encourage more rapid labor force exit and retirement, rather than supporting job seekers during a long search. Surprisingly, when the unemployment rate is high and new jobs are hard to find, retirement is only modestly more likely, with most of the effect 
concentrated in those who are eligible to claim Social Security benefits. But a longer duration in another public program - unemployment insurance benefits - has little effect on retirement timing. Finally, poor health and work-limiting disabilities are associated with more rapid labor force exit and retirement.

These results should be interpreted with some caution, because the sample of individuals who find themselves out of work late in their careers and choose not to immediately retire is nonrandom and possibly self-selected. While some of the key variables are exogenous to the individual's retirement or re-employment decision-making - age and the Social Security retirement benefit eligibility, state unemployment rate, and UI benefit duration - others, like net worth and the presence of a working spouse, are endogenous. The results may not be generalizable to all older workers and should not be interpreted as causal.

The brevity of jobless spells suggests that older individuals have little tolerance for job search, and those who can afford to make a quick exit - falling back on a substantial financial portfolio and annuities from Social Security and previous employers - will do so. The lack of evidence of an association between labor market conditions and the retirement decision indicates that one's impatience has little to do with the difficulty of the job search. Still, changes in recent decades that have eroded retirement security indicate that coming cohorts of older jobless people will not be able to afford the same haste to retire: defined benefit pensions and retiree health insurance coverage are all but extinct in the private sector, Social Security benefits replace a smaller proportion of each successive generation's income, and 401(k) balances do not make up for the shortfall. On the upside, workers in their 50s and 60s are healthier and better able to continue working, and have more general experience and less firm-specific capital than previous generations. All of these may better position them to take advantage of social networks to find jobs than younger competition. The uptick in the average duration of jobless spells portends longer job searches for older unemployed Americans, but their patience and persistence may pay off in rewarding second acts. 


\section{References}

Ai, Chunrong and Edward C. Norton. 2003. "Interaction Terms in Logit and Probit Models." Economic Letters 80(1): 123-129.

Autor, David H. and Mark G. Duggan. 2006. "The Growth in the Social Security Disability Rolls: A Fiscal Crisis Unfolding." Journal of Economic Perspectives 20(3): 71-96.

Benitez-Silva, Hugo and Na Yin. 2011. "Disability Insurance Applications near Retirement Age." State University of New York, Stony Brook working paper.

Bosworth, Barry P. and Gary Burtless. 2010. "Recessions, Wealth Destruction, and the Timing of Retirement." Working Paper 2010-22. Chestnut Hill, MA: Center for Retirement Research at Boston College.

Chan, Sewin and Ann Huff Stevens. 1999. "Employment and Retirement Following a LateCareer Job Loss." American Economic Review 89(2): 211-216.

Chan, Sewin and Ann Huff Stevens. 2004. "How Does Job Loss Affect the Timing of Retirement?" B.E. Journal of Economic Analysis and Policy 3(1): Contributions Article 5.

Coile, Courtney C. and Phillip B. Levine. 2007. "Labor Market Shocks and Retirement: Do Government Programs Matter?” Journal of Public Economics 91(10): 1902-1919.

Coile, Courtney C. and Phillip B. Levine. 2011a. "Recessions, Retirement and Social Security." American Economic Review, Papers and Proceedings 101(3): 23-28.

Coile, Courtney C. and Phillip B. Levine. 2011b. "The Market Crash and Mass Layoffs: How the Current Economic Crisis May Affect Retirement." B.E. Journal of Economic Analysis and Policy 11(1): Contributions Article 22.

Elsby, Michael W. L., Bart Hobijn, and Aysegul Sahin. 2013. "On the Importance of the Participation Margin for Labor Market Fluctuations.” Working Paper 2013-05. San Francisco, CA: Federal Reserve Bank of San Francisco.

Farber, Henry S. 2011. "Job Loss in the Great Recession: Historical Perspective from the Displaced Workers Survey, 1984-2010.” Working Paper 17040. Cambridge, MA: National Bureau of Economic Research.

Friedberg, Leora, Michael Owyang, and Anthony Webb. 2008. "Identifying Local Differences in Retirement Patterns." Working Paper 2008-18. Chestnut Hill, MA: Center for Retirement Research at Boston College.

Gustman, Alan L., and Thomas L. Steinmeier. 2002. "Retirement and the Stock Market Bubble." Working Paper 9404. Cambridge, MA: National Bureau of Economic Research. 
Hallberg, Daniel. 2011. "Economic Fluctuations and Retirement of Older Employees." LABOUR 25(3): 287-307.

Ham, John C., Xianghong Li, and Lara Shore-Sheppard. 2009. "Seam Bias, Multiple-State, Multiple-Spell Duration Models and the Employment Dynamics of Disadvantaged Women.” Working Paper 15151. Cambridge, MA: National Bureau of Economic Research.

Johnson, Richard W., and Barbara A. Butrica. 2012. "Age Disparities in Unemployment and Reemployment During the Great Recession and Recovery." Unemployment and Recovery Project Brief 3. Washington DC: Urban Institute.

Johnson, Richard W. and Corina Mommaerts. 2010. "Social Security Retirement Benefit Awards Hit All-Time High in 2009." Fact Sheet on Retirement Policy. Washington, DC: Urban Institute.

Marquis, Kent H. and Jeffrey C. Moore. 1990. "Measurement Errors in the Survey of Income and Program Participation (SIPP) Program Reports." 1990 Annual Research Conference Proceedings. Washington, D.C.: U.S. Bureau of the Census.

Muldoon, Dan and Richard W. Kopcke. 2008. "Are People Claiming Social Security Benefits Later?" Issue in Brief 8-7. Chestnut Hill, MA: Center for Retirement Research at Boston College.

Munnell, Alicia H. and Matthew S. Rutledge. 2013. "The Effects of the Great Recession on the Retirement Security of Older Workers." Annals of the American Academy of Political and Social Science, forthcoming.

Munnell, Alicia H., Mauricio Soto, Robert Triest and Natalia Zhivan. 2008. "How Much do State Economics and Other Characteristics Affect Labor Force Participation of Older Workers?" Working Paper 2008-12. Chestnut Hill, MA: Center for Retirement Research at Boston College.

Ryscavage, Paul. 1988. "Measuring Spells of Unemployment and Their Outcomes." SIPP Working Paper \#84. Washington, DC: U.S. Bureau of the Census.

Rothstein, Jesse. 2011. "Unemployment Insurance and Job Search in the Great Recession." Brookings Papers on Economic Activity, Fall 2011: 143-213.

Rutledge, Matthew S. 2012a. "The Impact of Unemployment Insurance Extensions on Disability Insurance Application and Allowance Rates." Working Paper 2011-17. Chestnut Hill, MA: Center for Retirement Research at Boston College.

Rutledge, Matthew S. 2012b. "Holding Out or Opting Out? Deciding between Retirement and Disability Applications in Recessions.” Working Paper 2012-26. Chestnut Hill, MA: Center for Retirement Research at Boston College. 
Rutledge, Matthew S. and Norma B. Coe. 2012. "Great Recession-Induced Early Claimers: Who Are They? How Much Did They Lose?” Working Paper 2012-12. Chestnut Hill, MA: Center for Retirement Research at Boston College.

Stevens, Ann Huff and Sewin Chan. 2001. "Job Loss and Employment Patterns of Older Workers.” Journal of Labor Economics 19(2): 484-521.

Tatsiramos, Konstantinos. 2010. "Job Displacement and the Transitions to Re-Employment and Early Retirement for Non-Employed Older Workers.” European Economic Review 54(4): 517-535.

von Wachter, Till. 2007. "The Effect of Economic Conditions on the Employment of Workers Nearing Retirement Age.” Working Paper 2007-25. Chestnut Hill, MA: Center for Retirement Research at Boston College.

Young, Nathan. 1989. "Wave Seam Effects in the SIPP: Implications for Analysis." Working Paper 8921. Washington, DC: U.S. Bureau of the Census. 
Figure 1. Unexplained Probability of Retirement and Labor Force Exit by Time since Job Separation

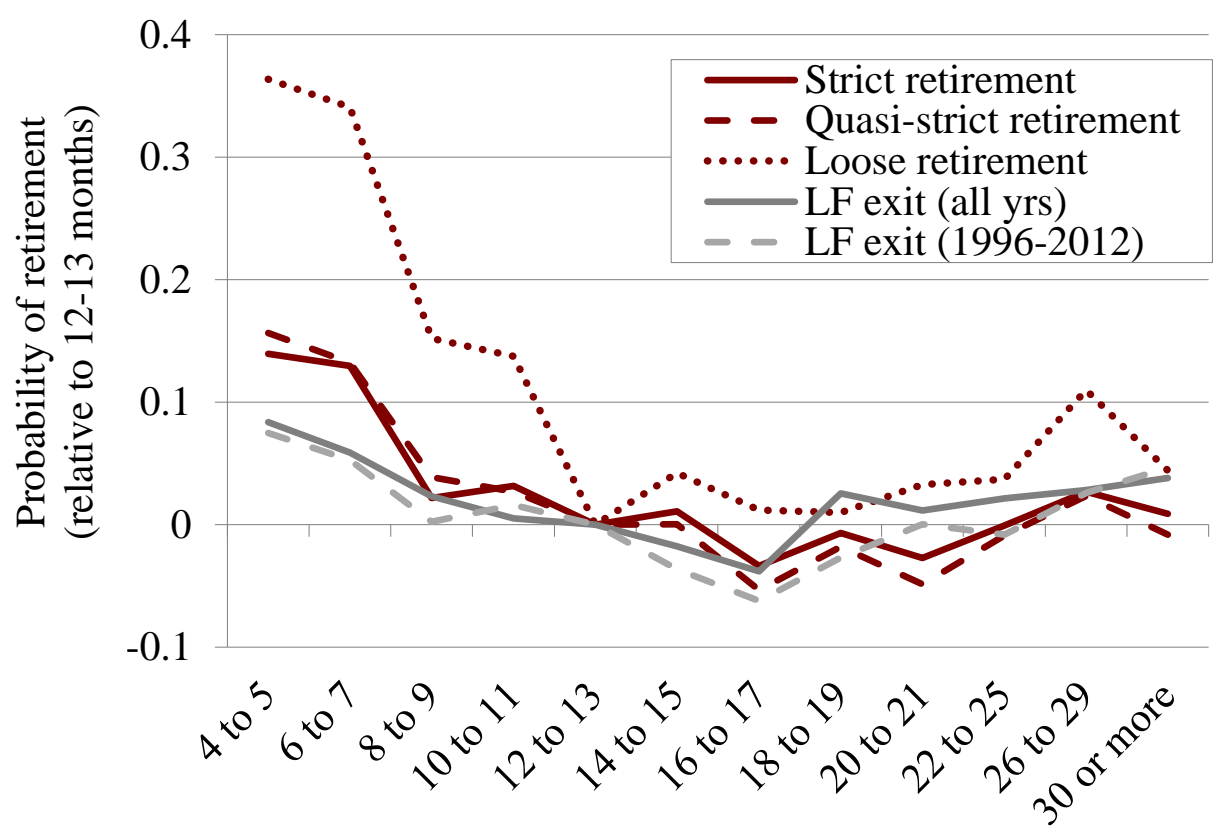

Months after job separation

Source: Author's estimates from the Survey of Income and Program Participation, 1990-2008 panels. 
Figure 2A. Predicted Probability of Retirement by Time Since Job Separation, Age, and Unemployment Rate, Age 55-61

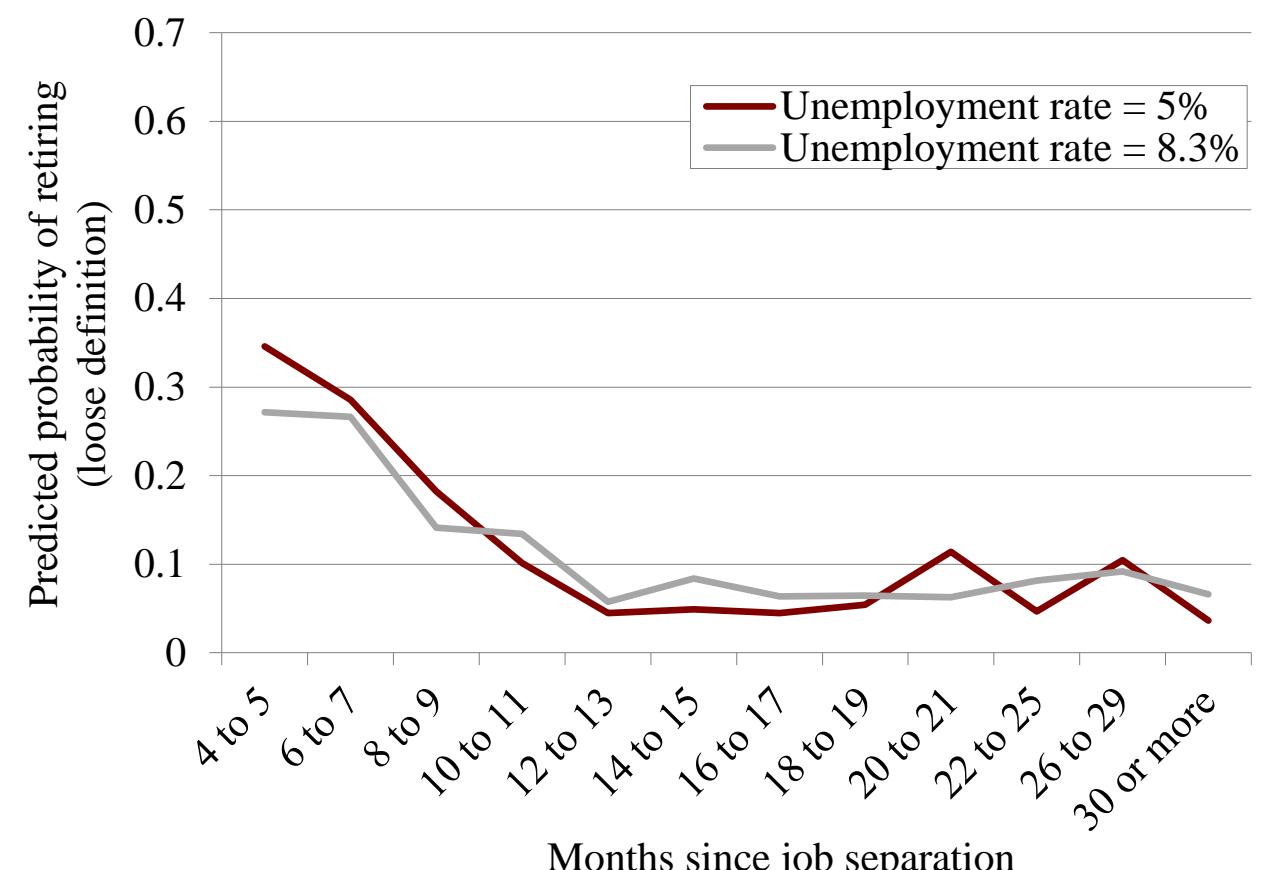

Figure 2B. Predicted Probability of Retirement by Time Since Job Separation, Age, and Unemployment Rate, Age 62-70

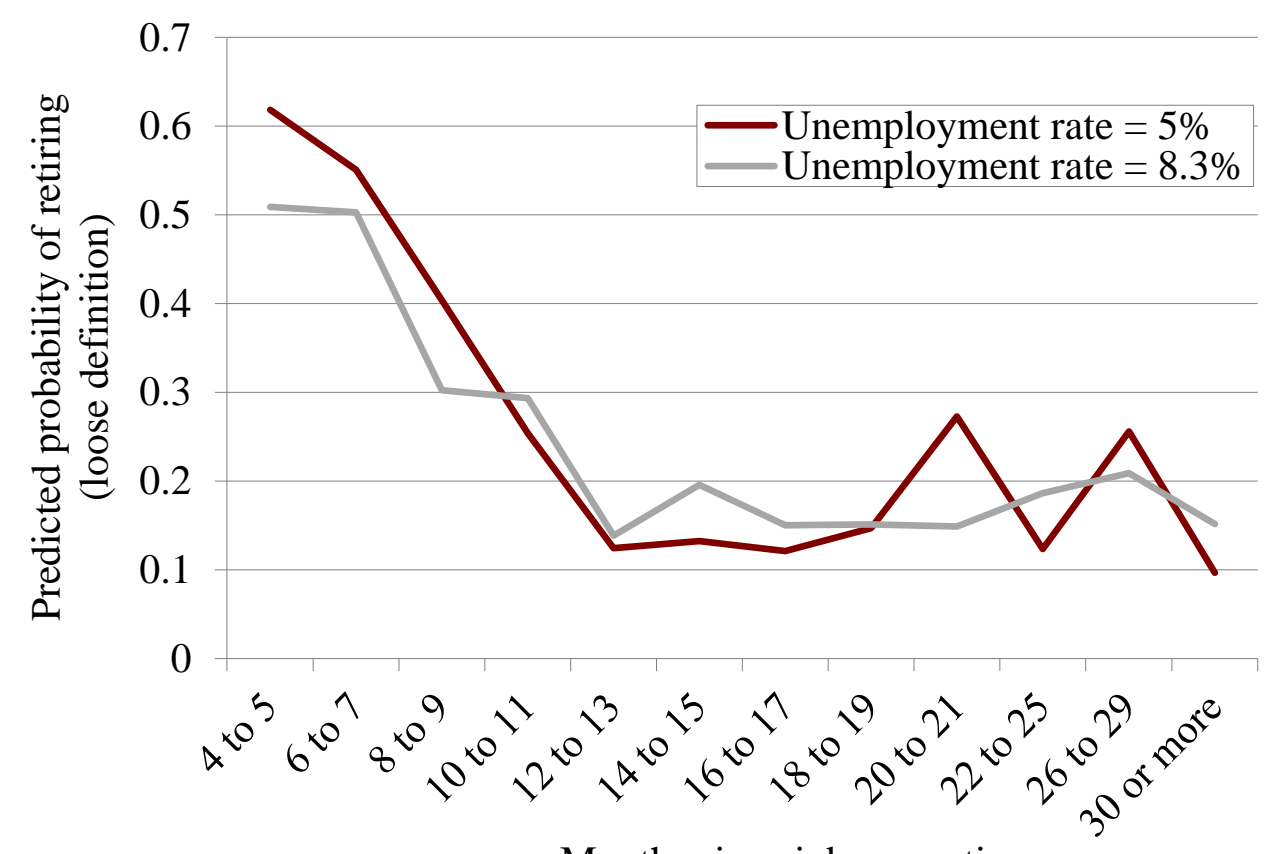

Months since job separation

Source: Author's estimates from the Survey of Income and Program Participation, 1996-2008 panels. 
Table 1. Sample Selection

Criterion

Remaining unique persons

SIPP 1990-2008 panels

716,412

Maximum age at least 55

156,276

At least one month of positive weeks worked

68,054

At least one job separation

22,441

Age 55 or over at job separation

22,427

Age 70 or under at job separation

17,154

Living in an identifiable state

16,889

\begin{tabular}{lr}
\hline Strict and quasi-strict retirement samples & \\
\hline 1996-2008 panels & 11,716 \\
Did not immediately retire & 6,764 \\
Not within three months of censoring & 6,460 \\
\hline & \\
\hline \multicolumn{2}{l}{ Loose retirement sample } \\
\hline 1996-2008 panels & 11,716 \\
Did not immediately retire & 4,956 \\
Not within three months of censoring & 4,702 \\
\hline & \\
\hline Labor force exit sample & 3,761 \\
\hline In labor force after separation & 3,405 \\
Not within five months of censoring & \\
\hline
\end{tabular}

Source: Author's calculations from Survey of Income and Program Participation, 1990-2008 panels. 
Table 2. Proportion of Spells Ending in Retirement, Re-Employment, and Censoring

\begin{tabular}{|c|c|c|c|}
\hline & Any retirement & Re-employment & Censored \\
\hline \multicolumn{4}{|l|}{ Period } \\
\hline 1996-2000 & 0.471 & 0.395 & 0.135 \\
\hline 2001-03 & 0.386 & 0.384 & 0.229 \\
\hline 2004-07 & 0.361 & 0.426 & 0.213 \\
\hline 2008-12 & 0.352 & 0.385 & 0.264 \\
\hline \multicolumn{4}{|l|}{ Age } \\
\hline 55-61 & 0.149 & 0.485 & 0.366 \\
\hline Around 62 & 0.240 & 0.330 & 0.431 \\
\hline$>62 \&<$ FRA & 0.225 & 0.333 & 0.442 \\
\hline Around FRA & 0.237 & 0.301 & 0.462 \\
\hline After FRA & 0.196 & 0.303 & 0.501 \\
\hline \multicolumn{4}{|l|}{ UI eligibility } \\
\hline Still on UI & 0.190 & 0.445 & 0.364 \\
\hline UI exhausted & 0.242 & 0.485 & 0.273 \\
\hline After UI & 0.065 & 0.190 & 0.745 \\
\hline \multicolumn{4}{|l|}{ Net worth quintile } \\
\hline Lowest & 0.174 & 0.421 & 0.405 \\
\hline 2nd & 0.190 & 0.435 & 0.374 \\
\hline $3 \mathrm{rd}$ & 0.191 & 0.415 & 0.394 \\
\hline 4th & 0.174 & 0.427 & 0.400 \\
\hline Highest & 0.184 & 0.399 & 0.416 \\
\hline \multicolumn{4}{|l|}{ Spouse work status } \\
\hline Unmarried & 0.185 & 0.404 & 0.411 \\
\hline Spouse working & 0.178 & 0.462 & 0.361 \\
\hline Spouse not working & 0.172 & 0.352 & 0.476 \\
\hline \multicolumn{4}{|c|}{ State unemployment rate tercile } \\
\hline Lowest & 0.176 & 0.414 & 0.410 \\
\hline Middle & 0.198 & 0.414 & 0.388 \\
\hline Upper & 0.167 & 0.402 & 0.431 \\
\hline \multicolumn{4}{|l|}{ DB pension } \\
\hline No & 0.175 & 0.423 & 0.403 \\
\hline Yes & 0.182 & 0.393 & 0.425 \\
\hline \multicolumn{4}{|l|}{ DC pension } \\
\hline No & 0.139 & 0.393 & 0.468 \\
\hline Yes & 0.294 & 0.453 & 0.254 \\
\hline \multicolumn{4}{|l|}{ Work limitation } \\
\hline No work limitation & 0.159 & 0.442 & 0.399 \\
\hline Work limitation & 0.249 & 0.280 & 0.471 \\
\hline \multicolumn{4}{|l|}{ Fair or poor health } \\
\hline Good health or better & 0.168 & 0.428 & 0.404 \\
\hline Fair or poor health & 0.217 & 0.332 & 0.451 \\
\hline
\end{tabular}

Source: Author's calculations from Survey of Income and Program Participation, 1996-2008 panels. 
Table 3. Average Duration of Spells Ending in Retirement and Re-Employment

\begin{tabular}{|c|c|c|c|}
\hline & Any retirement & Retirement vs job & Re-employment \\
\hline \multicolumn{4}{|l|}{ Period } \\
\hline 1996-2000 & 6.224 & $* * *$ & 5.466 \\
\hline $2001-03$ & 6.639 & $* * *$ & 5.907 \\
\hline 2004-07 & 6.747 & $* * *$ & 5.711 \\
\hline 2008-12 & 8.754 & $* *$ & 7.831 \\
\hline \multicolumn{4}{|l|}{ Age } \\
\hline $55-61$ & 7.381 & $* * *$ & 6.816 \\
\hline Around 62 & 9.349 & & 8.351 \\
\hline$>62 \&<\mathrm{FRA}$ & 7.463 & $* *$ & 6.846 \\
\hline Around FRA & 7.446 & & 6.476 \\
\hline After FRA & 6.542 & $* *$ & 7.139 \\
\hline \multicolumn{4}{|l|}{ UI eligibility } \\
\hline Still on UI & 6.148 & $* * *$ & 5.452 \\
\hline UI exhausted & 7.492 & $* * *$ & 8.148 \\
\hline After UI & 17.906 & $* * *$ & 15.308 \\
\hline \multicolumn{4}{|l|}{ Net worth quintile } \\
\hline Lowest & 7.314 & & 6.895 \\
\hline $2 \mathrm{nd}$ & 7.354 & & 7.165 \\
\hline $3 \mathrm{rd}$ & 7.957 & $* * *$ & 6.555 \\
\hline 4 th & 7.175 & & 6.888 \\
\hline Highest & 7.006 & & 7.032 \\
\hline N/A & 4.593 & $* *$ & 5.789 \\
\hline \multicolumn{4}{|l|}{ Spouse work status } \\
\hline Unmarried & 7.673 & $* * *$ & 6.974 \\
\hline Spouse working & 7.073 & & 6.792 \\
\hline Spouse not working & 7.061 & & 6.982 \\
\hline \multicolumn{4}{|c|}{ State unemployment rate tercile } \\
\hline Lowest & 6.599 & & 6.534 \\
\hline Middle & 7.061 & & 6.885 \\
\hline Upper & 7.696 & $* * *$ & 7.062 \\
\hline \multicolumn{4}{|l|}{ DB pension } \\
\hline No & 7.670 & $* * *$ & 6.888 \\
\hline Yes & 6.846 & & 6.917 \\
\hline \multicolumn{4}{|l|}{ DC pension } \\
\hline No & 7.051 & & 7.030 \\
\hline Yes & 7.553 & $* * *$ & 6.563 \\
\hline \multicolumn{4}{|l|}{ Work limitation } \\
\hline No work limitation & 7.099 & & 6.845 \\
\hline Work limitation & 7.662 & $*$ & 7.239 \\
\hline \multicolumn{4}{|l|}{ Fair or poor health } \\
\hline Good health or better & 7.038 & & 6.817 \\
\hline
\end{tabular}

Source: Author's calculations from Survey of Income and Program Participation, 1996-2008 panels. 
Table 4. Social Security Retirement Benefit Claiming by Age at Job Loss

\begin{tabular}{lrccc}
\hline \multicolumn{5}{l}{ Panel A. Claiming Age When Leaving Job Before 62 } \\
\cline { 2 - 5 } Age & All & Any retirement & Re-employment & Censored \\
\hline 62 & 42.5 & 48.9 & 35.3 & 43.6 \\
63 & 2.8 & 1.8 & 4.3 & 1.4 \\
64 & 0.7 & 0.3 & 0.9 & 1.1 \\
Not observed with OASI & 54.0 & 49.0 & 59.5 & 53.9 \\
\hline
\end{tabular}

Panel B. Claim Timing Relative to Job Separation After 62

\begin{tabular}{lc}
\hline & Percent \\
\hline Already receiving OASI & 53.2 \\
Same wave & 13.5 \\
Within six months & 3.0 \\
Within a year & 4.6 \\
More than 1 year later & 4.4 \\
Not observed with OASI & 21.4 \\
\hline
\end{tabular}

Note: Panel A includes anyone who lost a job before age 62 and is observed in SIPP after their 62nd birthday. Panel B includes anyone who lost a job at or after age 62.

Source: Author's calculations from Survey of Income and Program Participation, 1996-2008 panels. 
Table 5. Multinomial Logit Estimates for Re-Employment and Retirement

\begin{tabular}{|c|c|c|c|c|c|c|}
\hline \multirow[b]{2}{*}{ Dependent variable } & \multicolumn{2}{|c|}{$(1)$} & \multicolumn{2}{|c|}{$(2)$} & \multicolumn{2}{|c|}{ (3) } \\
\hline & $\begin{array}{c}\text { Re- } \\
\text { employment }\end{array}$ & $\begin{array}{c}\text { Strict } \\
\text { retirement } \\
\end{array}$ & $\begin{array}{c}\text { Re- } \\
\text { employment }\end{array}$ & $\begin{array}{l}\text { Quasi-strict } \\
\text { retirement }\end{array}$ & $\begin{array}{c}\text { Re- } \\
\text { employment }\end{array}$ & $\begin{array}{c}\text { Loose } \\
\text { retirement }\end{array}$ \\
\hline Mean hazard rate & 0.161 & 0.081 & 0.149 & 0.110 & 0.196 & 0.190 \\
\hline \multirow[t]{2}{*}{ State unemployment rate } & $-0.008 * * *$ & -0.001 & $-0.007 * * *$ & $-0.005 * * *$ & $-0.013 * * *$ & $-0.008 * * *$ \\
\hline & $(0.002)$ & $(0.001)$ & $(0.002)$ & $(0.002)$ & $(0.003)$ & $(0.003)$ \\
\hline \multirow[t]{2}{*}{ Age 62 or older } & $-0.018 * * *$ & $0.105^{* * *}$ & $-0.020 * * *$ & $0.132 * * *$ & $-0.043 * * *$ & $0.108 * * *$ \\
\hline & $(0.006)$ & $(0.008)$ & $(0.006)$ & $(0.008)$ & $(0.010)$ & $(0.010)$ \\
\hline \multirow[t]{2}{*}{ Still on UI } & $0.054 * * *$ & 0.017 & $0.068 * * *$ & 0.017 & 0.048 & -0.025 \\
\hline & $(0.017)$ & $(0.012)$ & $(0.020)$ & $(0.014)$ & $(0.030)$ & $(0.022)$ \\
\hline \multirow[t]{2}{*}{ UI exhausted } & $0.040 * * *$ & 0.014 & $0.059 * * *$ & 0.009 & $0.071 * *$ & -0.003 \\
\hline & $(0.014)$ & $(0.011)$ & $(0.017)$ & $(0.012)$ & $(0.031)$ & $(0.022)$ \\
\hline \multirow[t]{2}{*}{ Net worth $(\$ 100 \mathrm{k}, 2012)$} & $-0.003 * * *$ & $0.001 * *$ & $-0.003 * * *$ & $0.002 * * *$ & $-0.003 * *$ & $0.003 * * *$ \\
\hline & $(0.001)$ & $(0.000)$ & $(0.001)$ & $(0.001)$ & $(0.001)$ & $(0.001)$ \\
\hline \multirow[t]{2}{*}{ DB pension coverage } & 0.001 & $0.041^{* * *}$ & 0.001 & $0.066 * * *$ & 0.005 & $0.072 * * *$ \\
\hline & $(0.007)$ & $(0.006)$ & $(0.007)$ & $(0.007)$ & $(0.011)$ & $(0.009)$ \\
\hline \multirow[t]{2}{*}{ DC pension coverage } & $0.022 * * *$ & $-0.008 *$ & $0.023 * * *$ & -0.002 & $0.025 * *$ & -0.008 \\
\hline & $(0.008)$ & $(0.005)$ & $(0.008)$ & $(0.006)$ & $(0.013)$ & $(0.010)$ \\
\hline \multirow[t]{2}{*}{ Married } & $-0.024 * * *$ & 0.013 & $-0.025 * * *$ & $0.019 * *$ & -0.004 & $0.054 * * *$ \\
\hline & $(0.009)$ & $(0.008)$ & $(0.009)$ & $(0.010)$ & $(0.016)$ & $(0.013)$ \\
\hline \multirow[t]{2}{*}{ Spouse 62 or older } & -0.003 & 0.007 & -0.004 & $0.011 *$ & -0.011 & 0.007 \\
\hline & $(0.008)$ & $(0.007)$ & $(0.009)$ & $(0.007)$ & $(0.015)$ & $(0.012)$ \\
\hline \multirow[t]{2}{*}{ Spouse working } & 0.007 & $-0.026 * * *$ & 0.008 & $-0.026 * * *$ & 0.019 & -0.007 \\
\hline & $(0.008)$ & $(0.006)$ & $(0.009)$ & $(0.007)$ & $(0.015)$ & $(0.009)$ \\
\hline \multirow[t]{2}{*}{ Female } & $-0.042 * * *$ & -0.004 & $-0.044 * * *$ & $-0.014 * * *$ & -0.007 & $0.038 * * *$ \\
\hline & $(0.006)$ & $(0.005)$ & $(0.007)$ & $(0.005)$ & $(0.012)$ & $(0.009)$ \\
\hline \multirow[t]{2}{*}{ Work limitation } & $-0.149 * * *$ & $-0.052 * * *$ & $-0.150 * * *$ & $-0.089 * * *$ & $-0.082 * * *$ & $0.084 * * *$ \\
\hline & $(0.005)$ & $(0.005)$ & $(0.005)$ & $(0.005)$ & $(0.015)$ & $(0.011)$ \\
\hline \multirow[t]{2}{*}{ Fair or poor health } & $-0.037 * * *$ & $0.011^{*}$ & $-0.034 * * *$ & 0.005 & $-0.042 * * *$ & $0.031 * * *$ \\
\hline & $(0.008)$ & $(0.006)$ & $(0.009)$ & $(0.006)$ & $(0.015)$ & $(0.010)$ \\
\hline Sample size & 21,314 & & 20,240 & & 12,127 & \\
\hline
\end{tabular}

Note: Regression also includes educational attainment, race, Hispanic origin, citizenship, family income as a percent of the poverty line, year dummies, and indicators for months since jobless spell began.

Source: Author's estimates from Survey of Income and Program Participation, 1996-2008 panels. 
Table 6. Multinomial Logit Estimates for Re-Employment and Labor Force Exit

\begin{tabular}{|c|c|c|c|c|}
\hline \multirow[b]{2}{*}{ Dependent variable } & \multicolumn{2}{|c|}{ (1) } & \multicolumn{2}{|c|}{ (2) } \\
\hline & Re-employment & $\begin{array}{c}\text { LF Exit } \\
(1990-2012)\end{array}$ & Re-employment & $\begin{array}{c}\text { LF Exit } \\
(1996-2012)\end{array}$ \\
\hline Mean hazard rate & 0.246 & 0.080 & 0.230 & 0.082 \\
\hline State unemployment rate & $\begin{array}{l}-0.015 * * * \\
(0.004)\end{array}$ & $\begin{array}{l}-0.005^{* *} \\
(0.002)\end{array}$ & $\begin{array}{l}-0.018 * * * \\
(0.004)\end{array}$ & $\begin{array}{r}-0.003 \\
(0.002)\end{array}$ \\
\hline Age 62 or older & $\begin{array}{r}-0.015 \\
(0.011)\end{array}$ & $\begin{array}{l}0.108 * * * \\
(0.014)\end{array}$ & $\begin{array}{l}-0.049 * * * \\
(0.012)\end{array}$ & $\begin{array}{l}0.100 * * * \\
(0.015)\end{array}$ \\
\hline Still on UI & $\begin{array}{r}0.005 \\
(0.026)\end{array}$ & $\begin{array}{r}-0.020 \\
(0.021)\end{array}$ & $\begin{array}{r}0.036 \\
(0.030)\end{array}$ & $\begin{array}{r}-0.001 \\
(0.027)\end{array}$ \\
\hline UI exhausted & $\begin{array}{r}0.005 \\
(0.024)\end{array}$ & $\begin{array}{r}0.016 \\
(0.024)\end{array}$ & $\begin{array}{r}0.042 \\
(0.031)\end{array}$ & $\begin{array}{r}0.032 \\
(0.031)\end{array}$ \\
\hline Net worth $(\$ 100 \mathrm{k}, 2012)$ & $\begin{array}{l}-0.004 * * * \\
(0.001)\end{array}$ & $\begin{array}{r}0.000 \\
(0.001)\end{array}$ & $\begin{array}{l}-0.006 * * * \\
(0.002)\end{array}$ & $\begin{array}{l}-0.001 \\
(0.001)\end{array}$ \\
\hline DB pension coverage & $\begin{array}{r}0.006 \\
(0.011)\end{array}$ & $\begin{array}{l}0.035^{* * *} * \\
(0.010)\end{array}$ & $\begin{array}{l}-0.009 \\
(0.013)\end{array}$ & $\begin{array}{l}0.037 * * * \\
(0.012)\end{array}$ \\
\hline DC pension coverage & $\begin{array}{l}0.030 * * \\
(0.013)\end{array}$ & $\begin{array}{r}-0.003 \\
(0.010)\end{array}$ & $\begin{array}{r}0.013 \\
(0.014)\end{array}$ & $\begin{array}{r}0.005 \\
(0.011)\end{array}$ \\
\hline Married & $\begin{array}{l}0.041 * * \\
(0.016)\end{array}$ & $\begin{array}{l}0.033 * * \\
(0.015)\end{array}$ & $\begin{array}{l}0.032 * \\
(0.019)\end{array}$ & $\begin{array}{l}0.041 * * \\
(0.018)\end{array}$ \\
\hline Spouse 62 or older & $\begin{array}{l}-0.039 * * * \\
(0.012)\end{array}$ & $\begin{array}{r}-0.005 \\
(0.010)\end{array}$ & $\begin{array}{l}-0.030 * * \\
(0.015)\end{array}$ & $\begin{array}{r}-0.007 \\
(0.011)\end{array}$ \\
\hline Spouse working & $\begin{array}{r}0.012 \\
(0.014)\end{array}$ & $\begin{array}{l}-0.021 * * \\
(0.010)\end{array}$ & $\begin{array}{r}-0.004 \\
(0.015)\end{array}$ & $\begin{array}{l}-0.026 * * \\
(0.011)\end{array}$ \\
\hline Female & $\begin{array}{r}0.005 \\
(0.012)\end{array}$ & $\begin{array}{l}0.034 * * * \\
(0.011)\end{array}$ & $\begin{array}{r}0.012 \\
(0.013)\end{array}$ & $\begin{array}{l}0.023 * * \\
(0.011)\end{array}$ \\
\hline Work limitation & $\begin{array}{l}-0.042 * * * \\
(0.016)\end{array}$ & $\begin{array}{l}0.069 * * * \\
(0.013)\end{array}$ & $\begin{array}{l}-0.066 * * * \\
(0.016)\end{array}$ & $\begin{array}{l}0.086^{* * * *} \\
(0.017)\end{array}$ \\
\hline Fair or poor health & $\begin{array}{l}-0.036 * * * \\
(0.013)\end{array}$ & $\begin{array}{l}0.036^{* * * *} \\
(0.010)\end{array}$ & $\begin{array}{l}-0.046 * * * \\
(0.016)\end{array}$ & $\begin{array}{l}0.030 * * \\
(0.013)\end{array}$ \\
\hline Sample size & 9,443 & & 6,973 & \\
\hline
\end{tabular}

Note: Regression also includes educational attainment, race, Hispanic origin, citizenship, family income as a percent of the poverty line, year dummies, and indicators for months since jobless spell began.

Source: Author's estimates from Survey of Income and Program Participation, 1990-2008 panels. 
Table 7. Multinomial Logit Estimates for Retirement/LF Exit with Unemployment Rate Interactions

\section{(1)}

(2)

(3)

(4)

(5)

Dependent variable Strict retirement

Quasi-strict retirement

Mean hazard rate

State unemployment rate

0.081

0.110

Loose retirement

LF Exit (1990-2012)

LF Exit (1996-2012)

Age 62 or older

$$
\text { (0.008) }
$$

$-0.006$

)

(0.009)

$0.105^{* * *}$

$0.132 * * *$

$(0.010)$

$(0.011)$

$-0.005$

0.002

$(0.020)$

$(0.023)$

$-0.010$

$-0.009$

(0.018)

(0.020)

State unemployment rate $x$

Still on UI

$-0.001$

$(0.002)$

UI exhausted

$-0.002$

$(0.003)$

Around 62nd birthday

$$
0.007 * *
$$

$(0.004)$

(0.004)

Sample size

$$
0.002
$$

$(0.005)$

$-0.008$

$(0.008)$

0.001

$(0.007)$

(0.007)

$\begin{array}{ccc}0.190 & 0.080 & 0.082 \\ -0.009 & -0.005 & -0.003 \\ (0.015) & (0.010) & (0.012) \\ 0.107 * * * & 0.108^{* * *} & 0.099 * * * \\ (0.011) & (0.018) & (0.019) \\ -0.082^{*} & -0.050 & -0.062 \\ (0.048) & (0.034) & (0.046) \\ -0.059 & -0.018 & -0.017 \\ (0.044) & (0.039) & (0.061)\end{array}$

Note: The other outcome in each regression is re-employment, and each regression includes same controls as previous tables.

Source: Author's estimates from Survey of Income and Program Participation, 1990-2008 panels. 
Table 8. Multinomial Logit Estimates for Retirement and Labor Force Exit, by Age

\begin{tabular}{|c|c|c|c|c|c|c|}
\hline & $(1)$ & $(2)$ & (3) & $(4)$ & $(5)$ & (6) \\
\hline Age group & \multicolumn{2}{|c|}{$55-61$} & \multicolumn{2}{|c|}{62 - pre-FRA } & \multicolumn{2}{|c|}{ FRA and older } \\
\hline Dependent variable & Loose retire & LF Exit & Loose retire & LF Exit & Loose retire & LF Exit \\
\hline Mean hazard rate & 0.135 & 0.048 & 0.242 & 0.144 & 0.323 & 0.135 \\
\hline \multirow[t]{2}{*}{ State unemployment rate } & -0.002 & $-0.005^{* *}$ & -0.010 & -0.006 & $-0.023 * * *$ & -0.003 \\
\hline & $(0.003)$ & $(0.002)$ & $(0.007)$ & $(0.007)$ & $(0.009)$ & $(0.007)$ \\
\hline \multirow[t]{2}{*}{ Still on UI } & $-0.082 * * *$ & $-0.035^{*}$ & -0.035 & -0.013 & 0.044 & 0.023 \\
\hline & $(0.029)$ & $(0.019)$ & $(0.050)$ & $(0.053)$ & $(0.066)$ & $(0.077)$ \\
\hline \multirow[t]{2}{*}{ UI exhausted } & -0.043 & -0.004 & 0.008 & 0.037 & $0.115^{*}$ & 0.075 \\
\hline & $(0.029)$ & $(0.024)$ & $(0.051)$ & $(0.066)$ & $(0.067)$ & $(0.089)$ \\
\hline \multirow[t]{2}{*}{ Net worth $(\$ 100 \mathrm{k}, 2012)$} & $0.003 * * *$ & 0.000 & 0.003 & -0.005 & $0.006^{*}$ & 0.004 \\
\hline & $(0.001)$ & $(0.001)$ & $(0.002)$ & $(0.003)$ & $(0.003)$ & $(0.003)$ \\
\hline \multirow[t]{2}{*}{ DB pension coverage } & $0.095 * * *$ & $0.025 * *$ & $0.068 * * *$ & $0.087 * * *$ & 0.029 & 0.044 \\
\hline & $(0.014)$ & $(0.010)$ & $(0.021)$ & $(0.029)$ & $(0.024)$ & $(0.032)$ \\
\hline \multirow[t]{2}{*}{ DC pension coverage } & -0.012 & -0.001 & -0.011 & -0.003 & 0.037 & $-0.048^{*}$ \\
\hline & $(0.013)$ & $(0.011)$ & $(0.020)$ & $(0.025)$ & $(0.028)$ & $(0.028)$ \\
\hline \multirow[t]{2}{*}{ Married } & $0.063 * * *$ & $0.025^{*}$ & 0.044 & 0.025 & -0.029 & 0.046 \\
\hline & $(0.017)$ & $(0.014)$ & $(0.035)$ & $(0.034)$ & $(0.044)$ & $(0.050)$ \\
\hline \multirow[t]{2}{*}{ Spouse 62 or older } & -0.002 & -0.007 & 0.017 & 0.007 & $0.068 * *$ & -0.018 \\
\hline & $(0.019)$ & $(0.011)$ & $(0.027)$ & $(0.027)$ & $(0.033)$ & $(0.040)$ \\
\hline \multirow[t]{2}{*}{ Spouse working } & -0.006 & -0.015 & 0.003 & $-0.041 *$ & -0.014 & -0.021 \\
\hline & $(0.014)$ & $(0.010)$ & $(0.024)$ & $(0.024)$ & $(0.031)$ & $(0.035)$ \\
\hline \multirow[t]{2}{*}{ Female } & $0.058 * * *$ & $0.034 * * *$ & 0.007 & 0.007 & $-0.037^{*}$ & $0.072 * *$ \\
\hline & $(0.012)$ & $(0.012)$ & $(0.023)$ & $(0.027)$ & $(0.020)$ & $(0.034)$ \\
\hline \multirow[t]{2}{*}{ Work limitation } & $0.135 * * *$ & $0.072 * * *$ & $0.054 *$ & $0.075 * *$ & 0.001 & $0.073 *$ \\
\hline & $(0.016)$ & $(0.015)$ & $(0.028)$ & $(0.036)$ & $(0.027)$ & $(0.043)$ \\
\hline \multirow[t]{2}{*}{ Fair or poor health } & $0.034 * *$ & $0.034 * * *$ & 0.011 & 0.013 & -0.002 & 0.041 \\
\hline & $(0.014)$ & $(0.011)$ & $(0.024)$ & $(0.030)$ & $(0.023)$ & $(0.036)$ \\
\hline Sample size & 7,487 & 6,272 & 2,633 & 1,914 & 2,007 & 1,257 \\
\hline
\end{tabular}

Note: The other outcome in each regression is re-employment, and each regression includes same controls as previous tables. Labor force exit estimates are from 1990-2012 sample.

Source: Author's estimates from Survey of Income and Program Participation, 1990-2008 panels. 
Table 9. Multinomial Logit Estimates for Re-Employment and Retirement, by Period

\begin{tabular}{lcccc}
\hline & $(1)$ & $(2)$ & $(3)$ & $(4)$ \\
\cline { 2 - 5 } Period & $1996-2000$ & $2001-2003$ & $2004-2007$ & $2008-2012$ \\
\hline Dependent variable & Loose retire & Loose retire & Loose retire & Loose retire \\
\hline Mean hazard rate & 0.268 & 0.214 & 0.195 & 0.150 \\
\hline State unemployment rate & -0.015 & $-0.022^{*}$ & -0.008 & -0.003 \\
& $(0.012)$ & $(0.011)$ & $(0.011)$ & $(0.003)$ \\
Age 62 or older & $0.088^{* * *}$ & $0.129 * * *$ & $0.152^{* * *}$ & $0.112^{* * *}$ \\
Still on UI & $(0.026)$ & $(0.026)$ & $(0.027)$ & $(0.016)$ \\
UI exhausted & -0.045 & -0.040 & -0.029 & -0.048 \\
Net worth (\$100k, 2012) & $(0.106)$ & $(0.088)$ & $(0.089)$ & $(0.093)$ \\
DB pension coverage & -0.006 & -0.057 & 0.047 & -0.032 \\
Married & $(0.088)$ & $(0.078)$ & $(0.071)$ & $(0.089)$ \\
Spouse working & $0.003^{*}$ & $0.007 * * *$ & 0.001 & $0.002^{*}$ \\
Female & $(0.002)$ & $(0.002)$ & $(0.002)$ & $(0.001)$ \\
& $0.075^{* * *}$ & $0.122^{* * *}$ & 0.037 & $0.085^{* * *}$ \\
Work limitation & $(0.023)$ & $(0.027)$ & $(0.025)$ & $(0.017)$ \\
Fair or poor health & 0.052 & $0.071^{* *}$ & $0.064 *$ & $0.051^{* * *}$ \\
Sample size & $(0.040)$ & $(0.034)$ & $(0.037)$ & $(0.018)$ \\
& $-0.050^{*}$ & -0.032 & -0.007 & 0.002 \\
& $(0.026)$ & $(0.027)$ & $(0.028)$ & $(0.013)$ \\
& 0.036 & $0.050^{* *}$ & $0.044^{* *}$ & $0.027^{*}$
\end{tabular}

Note: The other outcome in each regression is re-employment, and each regression includes same controls as previous tables.

Source: Author's estimates from Survey of Income and Program Participation, 1996-2008 panels. 
Table 10. Multinomial Logit Estimates for Retirement/LF Exit excluding SSDI beneficiaries

\begin{tabular}{lccc}
\hline & $(1)$ & $(2)$ & $(3)$ \\
\hline Dependent variable & $\begin{array}{c}\text { Loose retirement } \\
\text { (Ages 55-70) }\end{array}$ & $\begin{array}{c}\text { Loose retirement } \\
\text { (Ages 55-61) }\end{array}$ & $\begin{array}{c}\text { LF Exit } \\
(1990-2012)\end{array}$ \\
\hline Mean hazard rate & 0.174 & 0.168 & 0.070 \\
\hline State unemployment rate & $-0.008^{* * *}$ & -0.003 & $-0.004^{*}$ \\
Age 62 or older & $(0.003)$ & $(0.005)$ & $(0.002)$ \\
Still on UI & $0.115^{* * *}$ & & $0.111^{* * *}$ \\
& $(0.011)$ & & $(0.015)$ \\
UI exhausted & $-0.039^{*}$ & $-0.077^{* *}$ & $-0.048^{* *}$ \\
Net worth (\$100k, 2012) & $(0.021)$ & $(0.036)$ & $(0.020)$ \\
DB pension coverage & -0.011 & -0.037 & -0.010 \\
Married & $(0.023)$ & $(0.037)$ & $(0.025)$ \\
Spouse working & $0.003^{* * *}$ & $0.004^{* * *}$ & 0.000 \\
Female & $(0.001)$ & $(0.001)$ & $(0.001)$ \\
& $0.073^{* * *}$ & $0.119^{* * * *}$ & $0.040^{* * *}$ \\
Work limitation & $(0.010)$ & $(0.018)$ & $(0.010)$ \\
Fair or poor health & $0.054^{* * *}$ & $0.081^{* * *}$ & $0.026^{*}$ \\
Sample size & $(0.015)$ & $(0.026)$ & $(0.016)$ \\
& -0.003 & -0.006 & -0.014 \\
& $(0.010)$ & $(0.019)$ & $(0.011)$ \\
& $0.042^{* * *}$ & $0.086^{* * *}$ & $0.041^{* * *}$ \\
& $(0.009)$ & $(0.016)$ & $(0.012)$ \\
& $0.051^{* * *}$ & $0.110^{* * *}$ & $0.048^{* * *}$ \\
& $(0.013)$ & $(0.022)$ & $(0.013)$ \\
& $0.026^{* * *}$ & $0.033^{*}$ & $0.029^{* *}$ \\
& $(0.011)$ & $(0.020)$ & $(0.012)$ \\
& 10,309 & 6,281 & 8,194 \\
\hline
\end{tabular}

Note: The other outcome in each regression is re-employment, and each regression includes same controls as previous tables.

Source: Author's estimates from Survey of Income and Program Participation, 1990-2008 panels. 
Table A1. Summary Statistics, by Spell Ending

\begin{tabular}{|c|c|c|c|c|c|c|c|}
\hline & $\begin{array}{c}\text { Any } \\
\text { retirement }\end{array}$ & $\begin{array}{c}\text { Retirement } \\
\text { vs job }\end{array}$ & $\begin{array}{c}\text { Re- } \\
\text { employment }\end{array}$ & $\begin{array}{c}\text { Job } \\
\text { vs cens }\end{array}$ & Censored & $\begin{array}{l}\text { Retirement } \\
\text { vs cens }\end{array}$ & $\begin{array}{c}\text { Labor } \\
\text { force exit }\end{array}$ \\
\hline State unemployment rate & $\begin{array}{r}6.664 \\
(0.076)\end{array}$ & & $\begin{array}{r}6.741 \\
(0.076)\end{array}$ & $* * *$ & $\begin{array}{r}7.489 \\
(0.134)\end{array}$ & $* * *$ & $\begin{array}{r}7.322 \\
(0.128)\end{array}$ \\
\hline Age & & & & & & & \\
\hline $55-61$ & $\begin{array}{r}0.495 \\
(0.012)\end{array}$ & $* * *$ & $\begin{array}{r}0.757 \\
(0.011)\end{array}$ & $* * *$ & $\begin{array}{r}0.669 \\
(0.022)\end{array}$ & $* * *$ & $\begin{array}{r}0.488 \\
(0.022)\end{array}$ \\
\hline Age 62 or older & $\begin{array}{r}0.505 \\
(0.012)\end{array}$ & $* * *$ & $\begin{array}{r}0.243 \\
(0.011)\end{array}$ & $* * *$ & $\begin{array}{r}0.331 \\
(0.022)\end{array}$ & $* * *$ & $\begin{array}{r}0.512 \\
(0.022)\end{array}$ \\
\hline Still on UI & $\begin{array}{r}0.798 \\
(0.007)\end{array}$ & $* * *$ & $\begin{array}{r}0.836 \\
(0.008)\end{array}$ & $* * *$ & $\begin{array}{r}0.772 \\
(0.018)\end{array}$ & & $\begin{array}{r}0.766 \\
(0.014)\end{array}$ \\
\hline UI exhausted & $\begin{array}{r}0.149 \\
(0.005)\end{array}$ & $* * *$ & $\begin{array}{r}0.124 \\
(0.005)\end{array}$ & $* * *$ & $\begin{array}{r}0.097 \\
(0.008)\end{array}$ & $* * *$ & $\begin{array}{r}0.132 \\
(0.008)\end{array}$ \\
\hline After UI & $\begin{array}{r}0.053 \\
(0.006)\end{array}$ & $*$ & $\begin{array}{r}0.040 \\
(0.005)\end{array}$ & $* * *$ & $\begin{array}{r}0.130 \\
(0.014)\end{array}$ & $* * *$ & $\begin{array}{r}0.101 \\
(0.010)\end{array}$ \\
\hline Net worth $(\$ 100 k, 2012)$ & $\begin{array}{r}3.224 \\
(0.136)\end{array}$ & $* * *$ & $\begin{array}{r}2.683 \\
(0.097)\end{array}$ & & $\begin{array}{r}2.411 \\
(0.163)\end{array}$ & $* * *$ & $\begin{array}{r}2.469 \\
(0.141)\end{array}$ \\
\hline N/A & $\begin{array}{r}0.005 \\
(0.002)\end{array}$ & & $\begin{array}{r}0.004 \\
(0.002)\end{array}$ & $* * *$ & $\begin{array}{r}0.019 \\
(0.003)\end{array}$ & $* * *$ & $\begin{array}{r}0.001 \\
(0.001)\end{array}$ \\
\hline DB pension coverage & $\begin{array}{r}0.471 \\
(0.014)\end{array}$ & $* * *$ & $\begin{array}{r}0.343 \\
(0.013)\end{array}$ & & $\begin{array}{r}0.316 \\
(0.024)\end{array}$ & & $\begin{array}{r}0.482 \\
(0.026)\end{array}$ \\
\hline DC pension coverage & $\begin{array}{r}0.434 \\
(0.012)\end{array}$ & $* * *$ & $\begin{array}{r}0.514 \\
(0.015)\end{array}$ & $* * *$ & $\begin{array}{r}0.473 \\
(0.024)\end{array}$ & $* * *$ & $\begin{array}{r}0.360 \\
(0.023)\end{array}$ \\
\hline Married & $\begin{array}{r}0.661 \\
(0.013)\end{array}$ & $* * *$ & $\begin{array}{r}0.612 \\
(0.015)\end{array}$ & $*$ & $\begin{array}{r}0.567 \\
(0.025)\end{array}$ & $* * *$ & $\begin{array}{r}0.612 \\
(0.025)\end{array}$ \\
\hline Spouse 62 or older & $\begin{array}{r}0.295 \\
(0.011)\end{array}$ & $* * *$ & $\begin{array}{r}0.157 \\
(0.009)\end{array}$ & & $\begin{array}{r}0.175 \\
(0.018)\end{array}$ & $* * *$ & $\begin{array}{r}0.261 \\
(0.020)\end{array}$ \\
\hline Spouse FRA or older & $\begin{array}{r}0.167 \\
(0.008)\end{array}$ & $* * *$ & $\begin{array}{r}0.085 \\
(0.006)\end{array}$ & & $\begin{array}{r}0.095 \\
(0.012)\end{array}$ & $* * *$ & $\begin{array}{r}0.143 \\
(0.017)\end{array}$ \\
\hline Spouse working & $\begin{array}{r}0.369 \\
(0.013)\end{array}$ & $* * *$ & $\begin{array}{r}0.417 \\
(0.013)\end{array}$ & $* * *$ & $\begin{array}{r}0.341 \\
(0.020)\end{array}$ & & $\begin{array}{r}0.338 \\
(0.021)\end{array}$ \\
\hline Female & $\begin{array}{r}0.512 \\
(0.012)\end{array}$ & $* * *$ & $\begin{array}{r}0.461 \\
(0.013)\end{array}$ & & $\begin{array}{r}0.479 \\
(0.019)\end{array}$ & & $\begin{array}{r}0.494 \\
(0.022)\end{array}$ \\
\hline White & $\begin{array}{r}0.856 \\
(0.009)\end{array}$ & & $\begin{array}{r}0.851 \\
(0.009)\end{array}$ & & $\begin{array}{r}0.833 \\
(0.014)\end{array}$ & & $\begin{array}{r}0.882 \\
(0.012)\end{array}$ \\
\hline Black & $\begin{array}{r}0.090 \\
(0.007)\end{array}$ & & $\begin{array}{r}0.099 \\
(0.008)\end{array}$ & & $\begin{array}{r}0.099 \\
(0.010)\end{array}$ & & $\begin{array}{r}0.085 \\
(0.010)\end{array}$ \\
\hline Asian & $\begin{array}{r}0.030 \\
(0.004)\end{array}$ & & $\begin{array}{r}0.026 \\
(0.005)\end{array}$ & & $\begin{array}{r}0.039 \\
(0.009)\end{array}$ & & $\begin{array}{r}0.016 \\
(0.004)\end{array}$ \\
\hline Other race & $\begin{array}{r}0.024 \\
(0.004)\end{array}$ & & $\begin{array}{r}0.024 \\
(0.004)\end{array}$ & & $\begin{array}{r}0.029 \\
(0.008)\end{array}$ & & $\begin{array}{r}0.017 \\
(0.005)\end{array}$ \\
\hline
\end{tabular}


Table A1. Summary Statistics, by Spell Ending (cont'd)

\begin{tabular}{|c|c|c|c|c|c|c|c|}
\hline & $\begin{array}{c}\text { Any } \\
\text { retirement }\end{array}$ & $\begin{array}{c}\text { Retirement } \\
\text { vs job }\end{array}$ & $\begin{array}{c}\text { Re- } \\
\text { employment }\end{array}$ & Job vs cens & Censored & $\begin{array}{c}\text { Retirement } \\
\text { vs cens }\end{array}$ & $\begin{array}{c}\text { Labor force } \\
\text { exit }\end{array}$ \\
\hline \multirow[t]{2}{*}{ Hispanic } & 0.094 & & 0.107 & & 0.125 & $*$ & 0.094 \\
\hline & $(0.009)$ & & $(0.010)$ & & $(0.016)$ & & $(0.012)$ \\
\hline \multirow[t]{2}{*}{ Native citizen } & 0.860 & $* *$ & 0.832 & $* * *$ & 0.772 & $* * *$ & 0.842 \\
\hline & $(0.009)$ & & $(0.012)$ & & $(0.017)$ & & $(0.017)$ \\
\hline \multirow[t]{2}{*}{ Noncitizen } & 0.046 & $* *$ & 0.066 & & 0.071 & $*$ & 0.037 \\
\hline & $(0.006)$ & & $(0.008)$ & & $(0.010)$ & & $(0.008)$ \\
\hline \multirow[t]{2}{*}{ Naturalized } & 0.066 & & 0.068 & & 0.069 & & 0.072 \\
\hline & $(0.007)$ & & $(0.007)$ & & $(0.010)$ & & $(0.011)$ \\
\hline \multirow[t]{2}{*}{ Citizenship N/A } & 0.028 & & 0.035 & $* * *$ & 0.088 & $* * *$ & 0.049 \\
\hline & $(0.004)$ & & $(0.005)$ & & $(0.011)$ & & $(0.010)$ \\
\hline \multirow[t]{2}{*}{ Less than high school } & 0.157 & $* *$ & 0.125 & & 0.137 & & 0.190 \\
\hline & $(0.010)$ & & $(0.010)$ & & $(0.013)$ & & $(0.016)$ \\
\hline \multirow[t]{2}{*}{ High school graduate } & 0.272 & $* * *$ & 0.232 & & 0.262 & & 0.325 \\
\hline & $(0.010)$ & & $(0.011)$ & & $(0.019)$ & & $(0.016)$ \\
\hline \multirow[t]{2}{*}{ Some college } & 0.331 & $*$ & 0.355 & & 0.370 & $*$ & 0.282 \\
\hline & $(0.010)$ & & $(0.012)$ & & $(0.021)$ & & $(0.015)$ \\
\hline \multirow[t]{2}{*}{ College graduate } & 0.241 & $* * *$ & 0.288 & $* * *$ & 0.231 & & 0.202 \\
\hline & $(0.011)$ & & $(0.013)$ & & $(0.017)$ & & $(0.014)$ \\
\hline \multicolumn{8}{|l|}{ Family income/poverty } \\
\hline \multirow[t]{2}{*}{$<100$ percent } & 0.066 & & 0.070 & & 0.091 & & 0.053 \\
\hline & $(0.005)$ & & $(0.007)$ & & $(0.014)$ & & $(0.011)$ \\
\hline \multirow[t]{2}{*}{$100-200$ percent } & 0.183 & $*$ & 0.159 & & 0.166 & & 0.187 \\
\hline & $(0.011)$ & & $(0.010)$ & & $(0.015)$ & & $(0.018)$ \\
\hline \multirow[t]{2}{*}{$200-300$ percent } & 0.186 & & 0.183 & & 0.202 & & 0.207 \\
\hline & $(0.008)$ & & $(0.009)$ & & $(0.017)$ & & $(0.018)$ \\
\hline \multirow[t]{2}{*}{$300-400$ percent } & 0.160 & & 0.163 & & 0.160 & & 0.151 \\
\hline & $(0.007)$ & & $(0.009)$ & & $(0.019)$ & & $(0.012)$ \\
\hline \multirow[t]{2}{*}{400 percent or more } & 0.405 & & 0.425 & $*$ & 0.382 & & 0.402 \\
\hline & $(0.012)$ & & $(0.014)$ & & $(0.022)$ & & $(0.023)$ \\
\hline \multirow[t]{2}{*}{ Work limitation } & 0.277 & $* * *$ & 0.116 & $* * *$ & 0.172 & $* * *$ & 0.247 \\
\hline & $(0.011)$ & & $(0.008)$ & & $(0.016)$ & & $(0.018)$ \\
\hline \multirow[t]{2}{*}{ Fair or poor health } & 0.246 & $* * *$ & 0.133 & $* *$ & 0.176 & $* * *$ & 0.260 \\
\hline & $(0.009)$ & & $(0.008)$ & & $(0.017)$ & & $(0.018)$ \\
\hline \multirow[t]{3}{*}{ Employer health insurance } & & & & & & & \\
\hline & 0.548 & $* * *$ & 0.599 & & 0.604 & $* *$ & 0.655 \\
\hline & $(0.011)$ & & $(0.013)$ & & $(0.019)$ & & $(0.020)$ \\
\hline Person-waves & 5,576 & & 5,152 & & 2,297 & & 1,941 \\
\hline Person-spells & 2,335 & & 2,396 & & 904 & & 760 \\
\hline
\end{tabular}

Note: First three columns are mutually exclusive; labor force exit is not.

Source: Author's calculations from Survey of Income and Program Participation, 1996-2008 panels. 